Check for updates

Cite this: Med. Chem. Commun., 2018, 9, 639

Received 21st November 2017,

Accepted 14th February 2018

DOI: $10.1039 / \mathrm{c} 7 \mathrm{md00593h}$

rsc.li/medchemcomm

\section{The critical role of novel benzophenone analogs on tumor growth inhibition targeting angiogenesis and apoptosis $\uparrow$}

\author{
Yasser Hussein Eissa Mohammed (D) ab and Shaukath Ara Khanum (D)*a
}

\section{Introduction}

Angiogenesis, which is considered one of the most crucial processes in tumor progression, is known to be the development of new blood vessels from the earlier vasculature. Angiogenesis which can set up its own particular blood supply is called tumor growth. ${ }^{1}$ The activity of many proangiogenic factors, a few examples of which are vascular endothelial growth factor (VEGF), fibroblast growth factors 1 and 2, tumor necrosis factor alpha, angiogenin, tumor growth factor beta, platelet-derived growth factor, angiopoietin and pleiotrophin, intercedes in the enlistment of new blood vessel growth by a tumor. $^{2,3}$ Vascular endothelial growth factor (VEGF) is one of the most important motivating factors responsible for ascites in ovarian hyperstimulation syndrome. It can be found in different tissues, including edema in the cerebrum, synovial fluid and malignant ascites. ${ }^{4}$ In the most human diseases, the

\footnotetext{
${ }^{a}$ Department of Chemistry, Yuvaraja's College, University of Mysore, Mysore 570005, Karnataka, India. E-mail: shaukathara@yahoo.co.in; Fax: +821 2419239; Tel: +919901888755

${ }^{b}$ Department of Biochemistry, Faculty of Applied Science College, University of Hajjah, Yemen

$\dagger$ Electronic supplementary information (ESI) available. See DOI: 10.1039/ c7md00593h
}

major part of the tumor cells mystery VEGF ${ }^{5}$ and VEGF mRNA is severely upregulated. ${ }^{6}$ The scale vessel thickness in breast cancer patients is strongly linked to VEGF expression. ${ }^{7}$ It has been clearly established that angiogenesis is vital for a tumor to undergo prominent expansive growth and become dangerous. Interference with the progression of angiogenesis through the inhibition or down-regulation of angiogenic factors may offer new opportunities for the treatment of tumors. The ability to increase, as well as to down-regulate, cell progression and to generate angiogenesis are mainly considered to be the major requirements for creating tumor neovasculature. Consequently, researchers have paid more attention to, and focused deeply on, the study of the expansion of antiangiogenesis and apoptosis as one of the predominant directions in current tumor treatment. The need for novel, powerful compounds with less or no toxicity and with different modes of action for focused treatment of tumor growth has led to creative methods and efforts directed toward finding such anti-cancer agents. ${ }^{8-10}$ Created by both natural and synthetic methods, benzophenones are a class of pharmacologically active molecules. Different analogues of benzophenones which are highly active as possible anti-tumor and antiangiogenic agents have been found and they are under clinical trials. The benzophenone moiety alone is not particularly 
active as an anti-tumor agent, as compared to benzophenone integrated with heterocyclic analogues. Therefore, to develop a potential approach to the discovery of anti-angiogenic drugs, benzophenones have been linked to a range of other medicinally important synthons; it is essential to create novel benzophenone analogues with different pharmacological targets. ${ }^{11,12}$ During this study, several assessments have been made of the anti-angiogenic and proapoptotic properties of benzophenone derivatives, and some benzophenone analogues have also been synthesized.

\section{Results and discussion}

\subsection{Chemistry}

Syntheses of the target compounds, 2-(4-benzoylphenoxy)aceto- $N(N$-methyl imidazole)carbonyl hydrazides $9 a-d$ and 2-(4-benzoylphenoxy)aceto- $N$ (pyrone-2-one)carbonyl hydrazides 10a-d, were performed according to the reactions illustrated in Scheme 1. The key starting compounds, phenyl benzoates 3a-d, were prepared according to the published procedures, ${ }^{11}$ starting from commercially available substituted phenols 1a-b with substituted benzoyl chlorides 2a-d. Fries rearrangement of compounds $3 \mathbf{a}-\mathbf{d}$ with anhydrous aluminum chloride as a catalyst gave hydroxybenzophenones $4 a-d$. Furthermore, etherification of $\mathbf{4 a - d}$ with bromoethyl acetate afforded the substituted ethyl esters 5a-d, which were converted to the corresponding acetohydrazides $6 \mathbf{6}-\mathbf{d}$ upon treatment with hydrazine hydrate. The corresponding final compounds 9a-d and 10a-d were successfully synthesized by coupling compounds $6 \mathbf{a}-\mathbf{d}$ with $N$-methyl imidazole-4carboxylic acid (7) and 2-oxo-2H-pyrone-5-carboxylic acid (8), respectively, using TBTU as a coupling reagent and lutidine as a base. All the structures of the newly synthesized compounds were assigned on the basis of their spectroscopic data, such as IR, NMR, and LC-MS, and also by C, H, N analysis. Compounds 3a-d, $\mathbf{4 a - d}$ and $\mathbf{5 a - d}$ had been synthesized<smiles>[R3]c1ccc(C(=O)c2cc(C(=O)c3cc([R2])c(O)c([R1])c3)ccc2[R3])cc1C(=O)Oc1c([R2])cccc1[R4]</smiles>

1a-b

2a-d

3a-d

4a-d<smiles>[R3]c1ccc(C(=O)c2cc([R2])c(OCC(=O)OCC)c([R4])c2)cc1</smiles><smiles>CC(C)[C@H](C)[C@H](C)O</smiles><smiles>[R3]c1ccc(C(=O)c2cc([R1])c(OCC(=O)NN)c([R])c2)cc1</smiles><smiles>[R3]c1ccc(C(=O)c2cc([R2])c(OCC(=O)NNC(=O)c3cn(C)cn3)c([R4])c2)cc1</smiles>

9a-d 10a: $R_{1}=H, R_{2}=H, R_{3}=H$

10b: $R_{1}=F, R_{2}=C l, R_{3}=F$

10c: $R_{1}=F, R_{2}=C l, R_{3}=C l$

10d: $\mathbf{R}_{1}=\mathrm{F}, \mathbf{R}_{2}=\mathrm{Cl}, \mathrm{R}_{\mathbf{3}}=\mathrm{CH}_{3}$

Scheme 1 Synthesis of novel benzophenone analogs (9a-d and 10a-d). 
and characterized earlier by our research group. ${ }^{15}$ The spectra of compound 6a were considered as representative examples of the series $6 \mathbf{a}-\mathbf{d}$. In the IR spectrum, compound $\mathbf{6 a}$ showed bands at 1610, 1645 and 3100-3205 $\mathrm{cm}^{-1}$, corresponding to aromatic carbonyl, amide carbonyl and $\mathrm{NH}-\mathrm{NH}_{2}$ stretching frequencies, respectively. In the ${ }^{1} \mathrm{H}$ NMR spectrum, compound 6a showed three singlets for $\mathrm{NH}_{2}, \mathrm{OCH}_{2}$ and $\mathrm{NH}$ at $\delta 4.35, \delta 4.89$ and $\delta 9.02$, respectively, and also showed multiplet signals in the range $\delta 7.01-8.86$ for aromatic protons. The mass spectrum of compound $6 \mathrm{a}$ gave a significant stable $\mathrm{M}+1$ peak at $\mathrm{m} / \mathrm{z} 270$. The IR spectra of compounds 9a and 10a showed new absorption bands for amide at 1735 $\mathrm{cm}^{-1}$ and $1725 \mathrm{~cm}^{-1}$, respectively, compared to compound $6 \mathrm{a}$, and also showed the disappearance of the $\mathrm{NH}_{2}$ protons peak of compound 6a. In addition, the ${ }^{1} \mathrm{H}$ NMR spectra of compounds 9d and 10a showed the disappearance of the $\mathrm{NH}_{2}$ proton peak at 4.35 and the appearance of new NH proton peaks at $\delta 10.39$ and 10.34, respectively. Also, there is an increase in aromatic protons in compounds 9d and 10a compared with compound $6 \mathrm{a}$, which revealed the formation of the title compounds 9a and 10a. The mass spectrum of compound 9a gave a significant stable peak at $\mathrm{m} / \mathrm{z} 379(\mathbf{M}+1)$ and the mass spectrum of 10a gave a peak at $\mathrm{m} / \mathrm{z} 392(\mathrm{M}+)$. Further, all the target compounds $9 a-\mathbf{d}$ and 10a-d were clearly confirmed by ${ }^{13} \mathrm{C}$ NMR spectroscopy.

\subsection{Biology}

2.2.1. Evaluation of $\mathrm{IC}_{50}$ values and in vitro selection of the lead compound. The benzophenone derivatives are known to be pharmacologically effective molecules against various pathological conditions including cancer. Earlier, our group reported the synthesis of benzophenones conjugated with thiazole, benzimidazole, coumarin and oxadiazole moieties with anti-tumor, anti-angiogenic and proapoptotic properties against various cell lines. ${ }^{11,14-18}$ On the other hand, according to a literature survey, imidazole and pyrone nucleus derivatives have excellent pharmacological characteristics against a variety of pathological conditions including cancers of different cells. In the present investigation, new potent analogues were synthesized, by integrating imidazole and pyrone nuclei with a benzophenone moiety. Initially, the anti-proliferative efficacy of benzophenone analogues 9a-d and 10a-d bearing imidazole and pyrone nuclei were evaluated against human cancer cells, such as human lung adenocarcinoma (A549), human cervical adenocarcinoma (HeLa), human breast adenocarcinoma (MCF-7) and normal fibroblast cells (NIH-3T3), by performing trypan blue, 3-(4,5dimethylthiazol-2-yl)-2,5-diphenyltetrazolium bromide (MTT) and lactate dehydrogenase (LDH) leakage assays [Table 1]. In this series, compound 9d was found to exhibit a promising anti-neoplastic effect in trypan blue and MTT assays, with half-maximal inhibitory concentration $\mathrm{IC}_{50}$ values of $9.6 \pm 1.7$ and $8.8 \pm 0.12 \mu \mathrm{M}$ in A549 cells, $10.2 \pm 0.3$ and $9.9 \pm 1.5 \mu \mathrm{M}$ in HeLa cells, and $9.5 \pm 0.7$ and $9.8 \pm 1.0 \mu \mathrm{M}$ in MCF-7 cells, respectively. Remarkably, compound 9d exhibited negligible

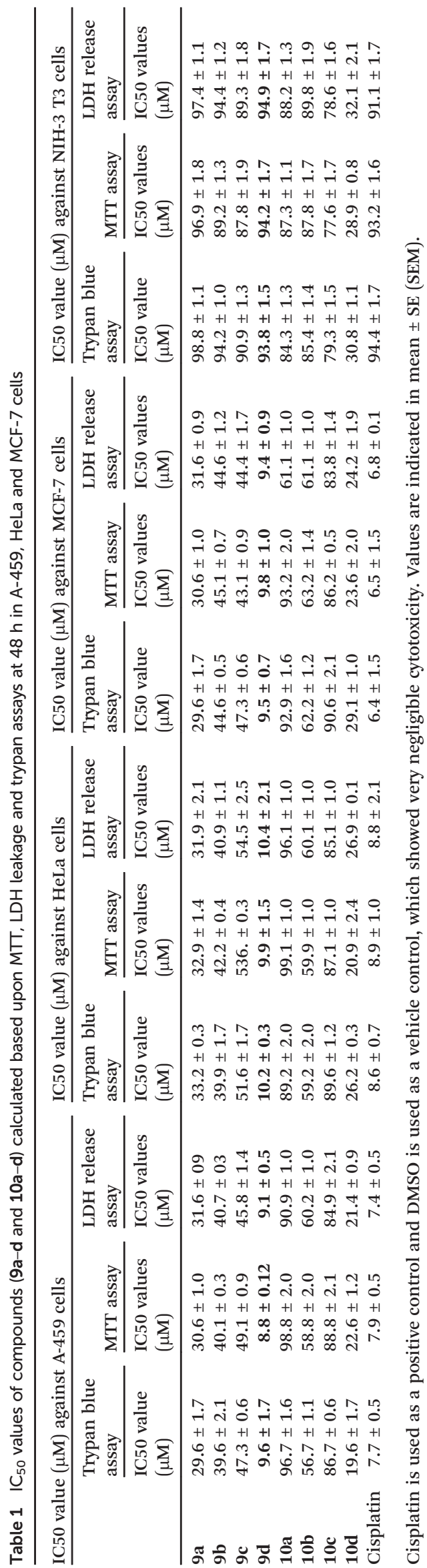




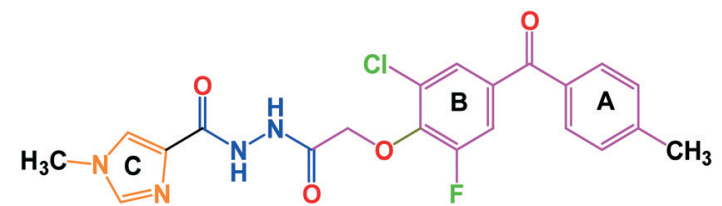

Fig. 1 The basic structure of $N^{\prime}$-(2-(2-chloro-6-fluoro-4-(4methylbenzoyl)phenoxy)acetyl)-1-methyl- $1 \mathrm{H}$-imidazole-4-carbohydrazide.

toxicity of $94.2 \pm 1.7 \mu \mathrm{M}$ to NIH-3T3 cells. The evaluation of cellular integrity using an LDH release assay is an incomparable method for assessing the cytotoxic effect of compounds. In our investigation, the results show a concentrationdependent increase in the release of $\mathrm{LDH}$ as the cells lose their integrity upon treatment with compound 9d, with $\mathrm{IC}_{50}$ values of $9.1 \pm 0.5,10.4 \pm 2.1$ and $9.4 \pm 0.9 \mu \mathrm{M}$ in A549, HeLa and MCF-7 cell lines, respectively. Altogether, these results suggest that compound 9d was potent and able to exhibit a cytotoxic effect against cells of different origin. The effect of compound 9d could be due to the presence of methyl, chloro and fluoro groups at the benzophenone moiety and also due to a methyl group on the imidazole ring, which is a unique difference from other compounds in the same series [Fig. 1]. Hence compound 9d was chosen as the lead compound and investigated further for its in vitro and in silico activities.

2.2.2. Structure-activity relationship (SAR). Compounds which contain benzophenone pharmacophores are known to be pharmacologically active molecules which are utilized against several pathological conditions including cancer. ${ }^{16,19,20}$ A multistep synthesis of benzophenone containing imidazole and pyrone analogues is involved in our current study. It is apparent that compound 9d, which contains the same backbone structure of benzophenone with an aceto moiety and $N$-methyl imidazole ring as other members of the same series but with a methyl group in the benzophenone moiety, has shown good activity compared to others in the same series. The $\mathrm{IC}_{50}$ values shown in Table 1 suggest that compound 9d with methyl, chloro and fluoro groups in the benzophenone moiety and another methyl group on the imidazole ring has an average $\mathrm{IC}_{50}$ value of $\sim 9.6 \mu \mathrm{M}$, as verified by trypan blue, MTT and LDH release assays. The results illustrated that compound 9a without a halo group, or $9 \mathrm{~b}$ and 9c with chloro and fluoro groups, show decreased activity compared to 9d [Table 1]. This reveals that compound 9d with methyl, chloro and fluoro groups in the benzophenone moiety and a methyl group on the imidazole ring [Fig. 1] is an important compound for biological activity, whereas other compounds with different substituents have shown poor cytotoxicity [Table 1]. Therefore, compound 9d was selected as the lead compound based on its significant structure-activity relationship compared with the other analogues and it was further evaluated by in vitro, in vivo and in silico studies.

2.2.3. Compound 9d exhibits prolonged anti-mitogenicity activity. A colony formation assay is an appropriate method for investigating the long-term anti-mitogenicity of cytotoxic molecules in cancer cell proliferation. Reticence in colony formation is considered a prolonged cytotoxic effect of an active biomolecule. ${ }^{13}$ In this analysis, A549 cells were treated with or without compound 9d to analyze its long-term effect. The results revealed that compound 9d visibly diminished the clonogenic efficiency of A549 cells. Compound 9d was found to inhibit colony formation of A549 cells by 25 and 50 $\mu \mathrm{M}$ compared to the standard, cisplatin [Fig. 2a and c], and the density of colony formation was remarkably reduced by compound 9d, as is apparent from a microscopic analysis of the colonies [Fig. 2b].

2.2.4. Compound 9d counteracts cancer cell migration. Most cancers, including lung, liver, renal, cervical and breast cancer, are extremely metastatic, with increased migration and invasive characteristics. ${ }^{13,21}$ To understand the role of

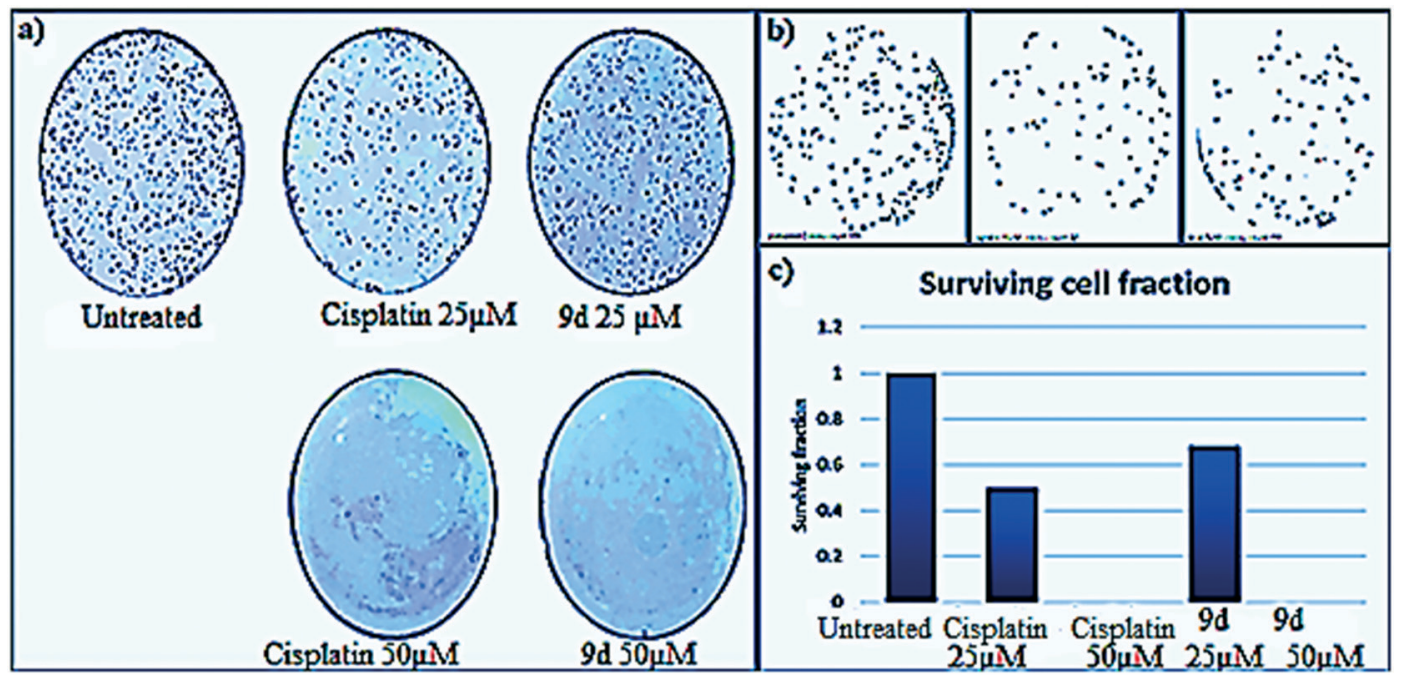

Fig. 2 Compound 9d exhibits prolonged activity. a) A549 cells were pretreated with compound $9 \mathrm{~d}(25 \mu \mathrm{M}$ and $50 \mu \mathrm{M})$ for $6 \mathrm{~h}$ and incubated for a period of 12 days to form colonies. b) Mask colony counts of untreated, $25 \mu \mathrm{M}$ cisplatin-treated and $25 \mu \mathrm{M}$ compound $9 \mathrm{~d}$-treated cells. c) Graphical representation of inhibition of colony formation. Statistically significant values are expressed $* p<0.05$ and $* * p<0.01$. 
compound 9d in migration, we performed a scratch wound assay with A549 cells which are highly migratory in vitro. Cell migration into the wound was quantified by taking snapshots with a regular inverted microscope at 0 and $48 \mathrm{~h}$ post-scratch. The A549 cells migrated over a period of $48 \mathrm{~h}$ to fill the wound. However, cells treated with compound 9d failed to migrate into the wound and exhibited an inhibition of $78.83 \%$ and $15.59 \%$ at $50 \mu \mathrm{M}$ and $25 \mu \mathrm{M}$, respectively [Fig. 3a-d]. Therefore, compound 9d has the potency to counteract angiogenesis and metastasis by targeting cancer cell migration.

2.2.5. Compound 9d potentially inhibits neovascularization in non-tumor model systems. To investigate its antiangiogenic activity, compound 9d was tested in different angiogenesis models induced by $\mathrm{rVEGF}_{165}$. Based on SAR, compound 9d with chloro, fluoro and methyl groups in the benzophenone moiety and a methyl group on the imidazole moiety showed the highest $\mathrm{IC}_{50}$ value in all assays by in vitro studies, which led us to select compound 9d for in vivo studies, in which it showed an effect on VEGFr in different chorioallantoic membrane (CAM) assays. Also, it decreased the VEGF protein levels most effectively, as measured by the decrease in blood vessels in CAM. The total number of sprouting vessels was quantified by considering the rVEGF $_{165}$-induced control as $100 \%$ in in vivo CAM and ex vivo CAM. $^{2,14}$ The phosphate buffered saline (PBS) alone treated in normal developing CAM was found to be $20 \%$ of growing blood vessels in both in vivo, and ex vivo CAM assays. A clear avascular zone around the implanted disc with compound 9d was clearly evident for the regression of neovessels in the developing embryos in both in vivo and ex vivo CAM [Fig. 4a and b], with inhibitions of 24 and 26\%, respectively. The total vessel length in compound 9d-treated eggs was drastically decreased by $\sim 85 \%$ compared to untreated eggs in both assays [Fig. 4d and e]. To re-evaluate the effect of compound 9d on neovascularization in angiogenesis-dependent tumor progression, a CAM xenograft was performed using A549 cells with rVEGF $_{165}$. The results show that compound 9d and cisplatin evidently reduced the tumor progression by 1.7 and 4.0-fold, respectively. These results are based on the decrease in rVEGF $_{165}$-induced micro vessel density (MVD)/ HPF for compound 9d of $3.6 \pm 1.6(86.2 \%)$ and for cisplatin of $9.1 \pm 2.5(52.2 \%)$, compared to that of untreated CAM of $30.1 \pm 1.5$, in a concentration-dependent manner [Fig. $4 \mathrm{c}$ and $\mathrm{f}$ ].

2.2.6. Effect of compound 9d on the morphology of A549 cells. The inhibitory effect of compound 9d on A549 cell growth may be due to induction of apoptosis. The A549 cells were stained with Giemsa and the slides were observed under a microscope. In Fig. 5, dead cells were lightly stained and had an irregular cell membrane compared to the darkly stained and spherical live cells. a)

c)
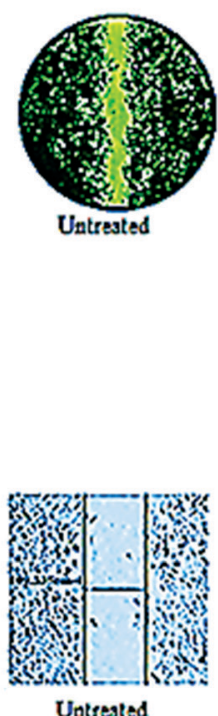

Untrested
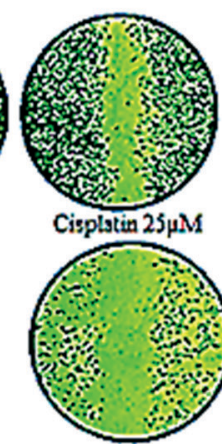

Cisplatin $50 \mu \mathrm{M}$

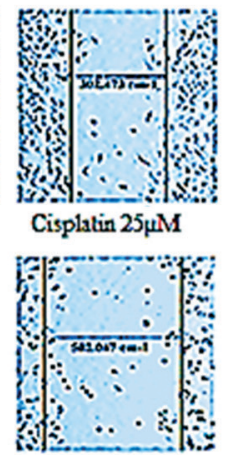

Cisplatin $50 \mu \mathrm{M}$
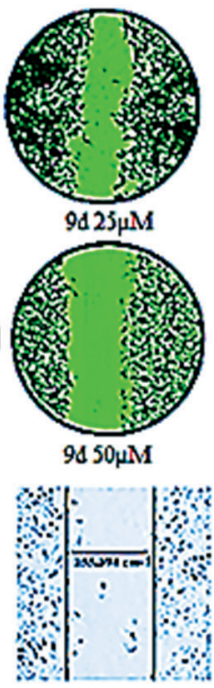

$9 \mathrm{~d} 25 \mu \mathrm{M}$

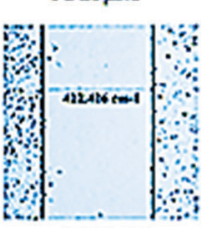

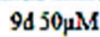

b)

$\%$ Inlibition of the Migration

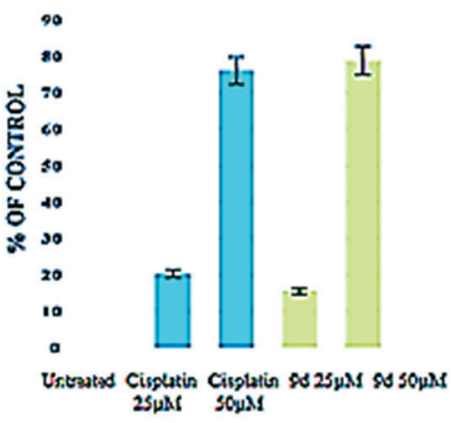

d)

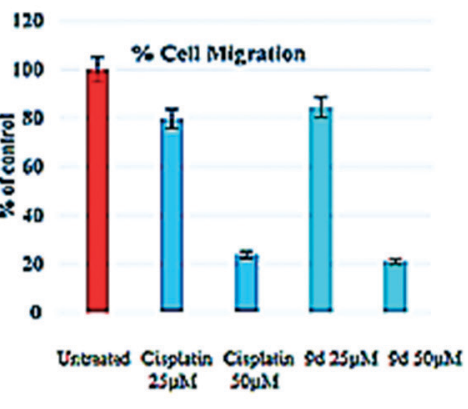

Fig. 3 a) Compound $9 \mathrm{~d}$ exhibited an inhibition of migration of $A 549$ cells of $78.83 \%$ and $15.59 \%$ at $50 \mu \mathrm{M}$ and $25 \mu \mathrm{M}$, respectively, whereas standard cisplatin showed inhibition of $76.13 \%$ and $20.25 \%$ at $50 \mu \mathrm{M}$ and $25 \mu \mathrm{M}$, respectively. b) Graphical representation of inhibition of A549 cancer cell migration. c) The A549 monolayers were scratched to form a wound and treated with compound $9 \mathrm{~d}$ for $48 \mathrm{~h}$ and pictures of the migrated cells were taken using a microscope with a 10x objective (total magnification 100x). d) Graphical representation of cancer cell migration; statistically significant values are expressed as $* p<0.05$ and $* * p<0.01$ 


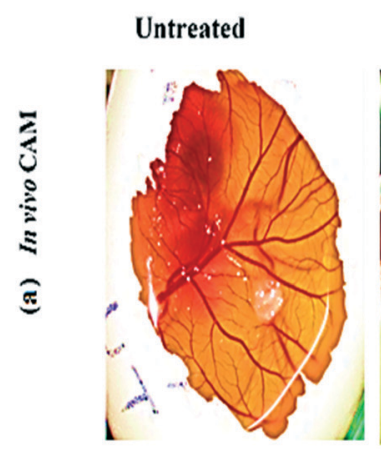

Cisplatin + VEGF 165
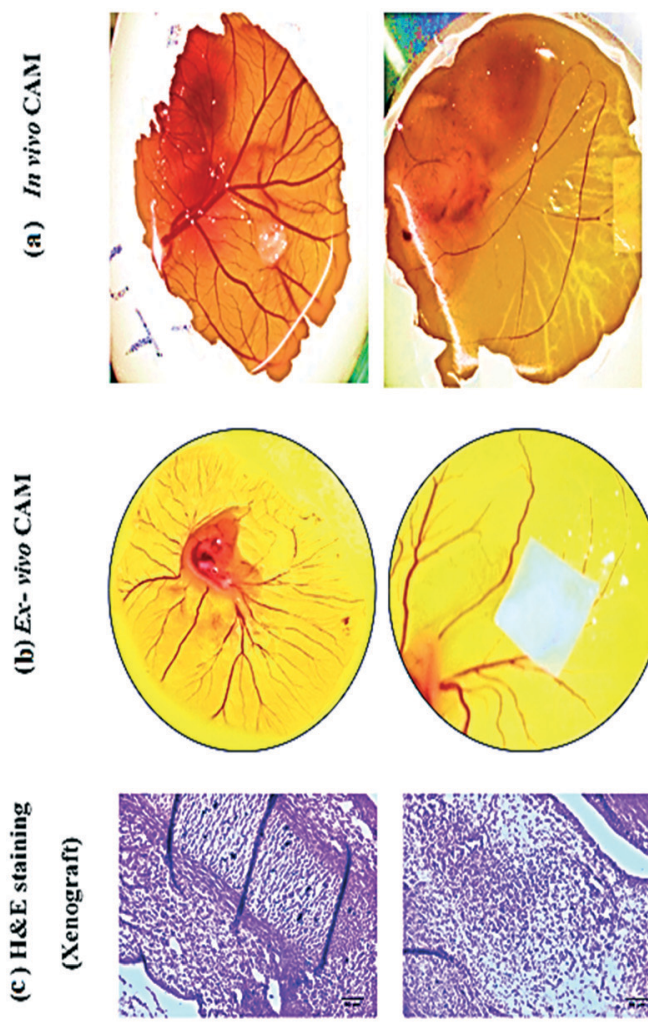
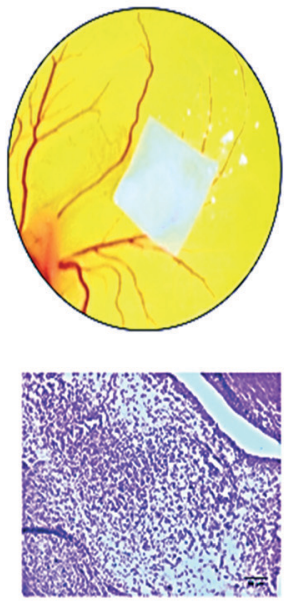

Compound 9d+VEGF $F_{16 s}$
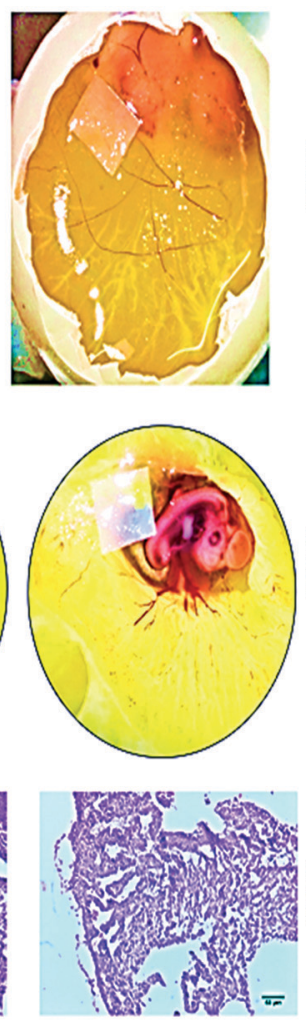

d) Microvessel Density

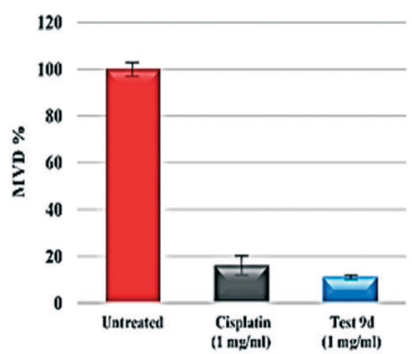

e) Microvessel Density

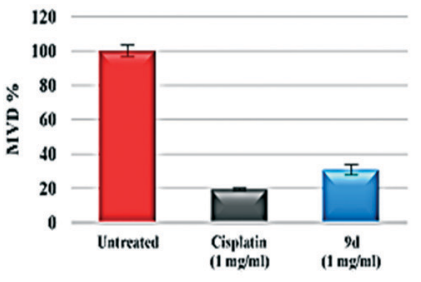

f) Microvessel density

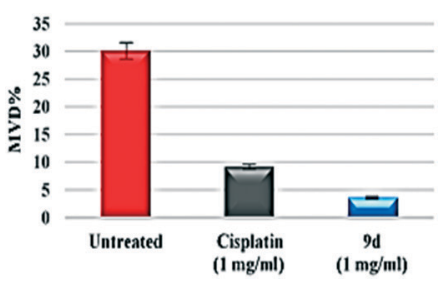

Fig. 4 In vivo CAM photographs showing the inhibition of neovessel formation. a) The in vivo CAM photos show the angiopreventive effect of compound 9d-treated CAM compared to $\mathrm{VEGF}_{165^{-}}$and standard cisplatin and $\mathrm{VEGF}_{165^{-}}$-treated CAM. b) The ex vivo CAM photos exhibit the angiopreventive effect of compound $9 \mathrm{~d}$ compared to $\mathrm{VEGF}_{165}$ and standard cisplatin and $\mathrm{VEGF}_{165}$ treatment. C) $\mathrm{H}$ - and-E-stained micrographs showing tumor inhibitory potential in A549 xenograft tumor sections, confirming the reduced MVD/HPF with compound 9d. Magnification of the micrograph is 40x. d) Graphical representation of the MVD count in untreated, standard cisplatin-treated, and compound 9d-treated in vivo CAM. e) Graphical representation of the MVD count in untreated, and standard cisplatin- and compound 9d-treated ex vivo CAM. f) Percentage of A549 tumor MVD inhibition. Statistically significant values are expressed as $* p<0.05$ and $* * p<0.01$.

2.2.7. Induction of endonuclease upon treatment with compound 9d. Endonucleases are essential for DNA fragmentation, which is a prominent feature of apoptosis. ${ }^{3,14}$ Endonuclease assay results showed that compound 9d promoted endonuclease activation, as visualized by the DNA lysis zone [Fig. 6a and b]. Furthermore, a molecular event of compound 9d was analyzed by immunoblot, where it exhibited tumor inhibition [Fig. 6c]. Additionally, the degradation of DNA into multiple intermolecular small fragments of 180-200 base pairs is a distinct biochemical trait of apoptosis. Nuclear DNA treated with or without compound 9d was analyzed by agarose gel electrophoresis. ${ }^{14}$ The results confirmed the typical "ladder" formation of DNA treated with compound 9d, whereas the DNA from untreated cells did not show any
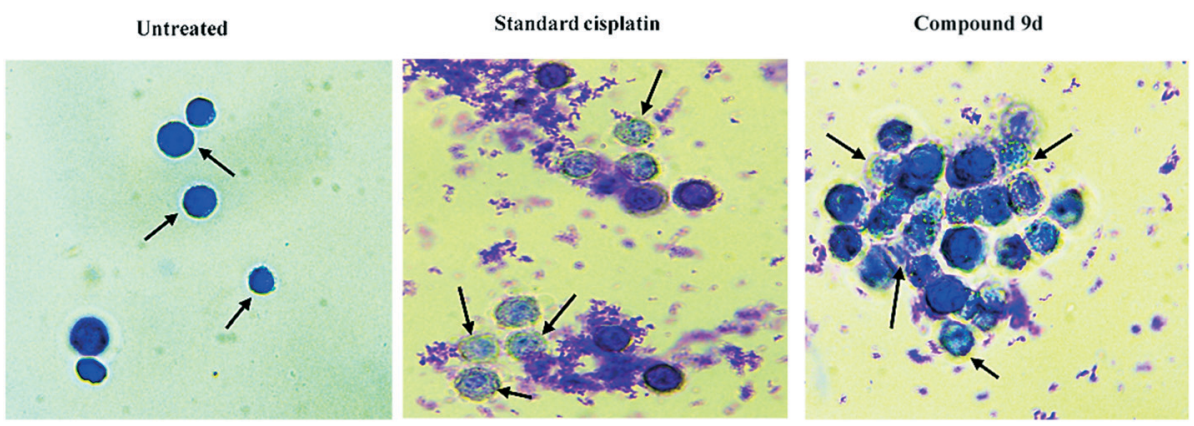

Fig. 5 Giemsa-stained A549 cells showing the morphological changes, such as irregular shape, membrane blebbing and formation of apoptotic bodies, in standard cisplatin- and compound $9 \mathrm{~d}$-treated cells, compared to untreated cells. 
a) d) Control Marker $9 \mathrm{~d}$

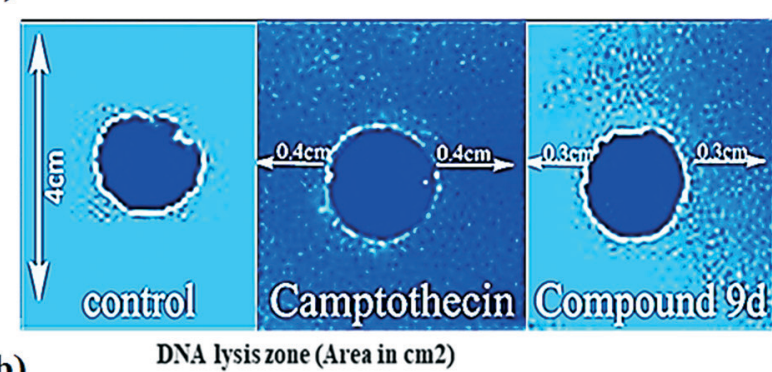

b)

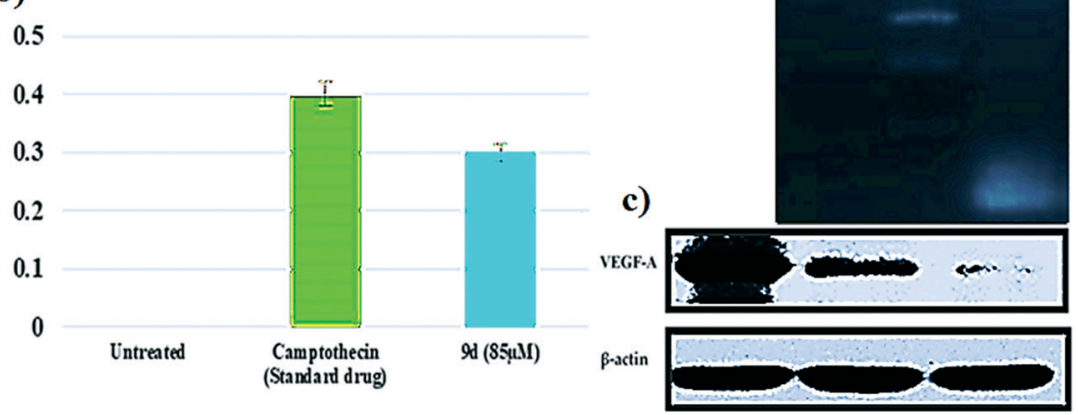

Fig. 6 a) Endonuclease assay showing the DNA lysis zone in cytosolic fractions treated with camptothecin and compound 9d as observed compared to the control. b) The graphical representation of the percentage of the DNA lysis zone in cytosolic fractions. c) Reduction in translational VEGF expression compared to control. d) Agarose gel electrophoresis for DNA fragmentation assay (apoptotic ladder) showing lane 1 as control, lane 2 as marker (DNA ladder) and cells treated with compound $9 \mathrm{~d}$ in lane 3 . Statistically significant values are expressed as $* p<0.05$ and $* * p<0.01$.

changes and a single band was observed on the agarose gel. This study confirms that the anti-angiogenesis effects of benzophenone analogues are mediated through apoptosis, leading to DNA degradation [Fig. 6d].

2.2.8. Compound 9d induces apoptosis on A549 cells. To elucidate the possible mechanism of compound 9d-mediated tumor inhibition, the effect of compound 9d on A549 cells was investigated. The treatment of A549 cells with compound 9d induced a significant proportion of cells to undergo apoptosis, as determined by flow cytometric analysis. ${ }^{13}$ The flow cytometric analysis of the cells indicates the formation of apoptotic bodies and condensed cells with standard camptothecin and control. Upon receiving compound 9d treatment, some of the A549 cells undergo apoptosis and are detected in the sub- $\mathrm{G}_{2}$ area [Fig. 7a and b]. Furthermore, compound 9d promotes apoptotic cell death by caspase-3 activation. A molecular event of compound 9d exhibiting tumor regression was analyzed by immunoblot [Fig. 7c]. These results suggested breakage of DNA in A549 cells, resulting in tumor killing. The obvious corollary is the arrest of the growth of the A549 cells.

2.2.9. Influence of compound 9d on $A 549$ cell cycle arrest. Compound 9d induces cell cycle arrest in A549 cells in vitro. Flow cytometric cell cycle analysis was performed using propidium iodide (PI) DNA staining ${ }^{13}$ of A549 cells following $48 \mathrm{~h}$ of treatment with $85 \mu \mathrm{M}$ of compound 9d. For A549 cell cycle analysis, compound 9d showed arrest in the G2/M phase $24 \mathrm{~h}$ after treatment. However, at $48 \mathrm{~h}$, the cells arrested in the G2/M phase underwent cell death, as evidenced by the increase in the sub-G0 percentage [Fig. $8 \mathrm{a}$ and $\mathrm{b}$ ].
2.2.10. Docking of inhibitors with the active site of VEGF. The AutoDock program was utilized to produce a protein-9d complex, in order to understand the interaction between VEGF protein and ligand 9d. It can clearly be seen that ligand 9d is placed in the center of the active site and it is stabilized by hydrogen bonding interactions. The hydrogen bonds exhibited in the VEGF-9d complex have been documented, together with their distances and angles. By taking into account the interaction energies of $9 \mathrm{~d}$ with residues in the active site of the VEGF, key binding residues in the active site of the model were determined and proved. This is important evidence, and it can clearly prove the relative significance of each residue in a positive restriction interaction, showing the binding energy, ligand efficiency, inhibition constant, van der Waals force, hydrogen bonds, desolvation energy, bonding residues score, and bond length score for the active site of the VEGF-9d complex compared to compound 9d [Table 2]. It is obvious that the VEGF-9d complex has substantial perfect with bonding energies $-7.66 \mathrm{~kJ} \mathrm{~mol}^{-1}$ [Fig. 9]. For the protein complex interaction, we have to take into consideration all the important factors mentioned earlier. It was proved by the interaction analysis that ARG842, ASN923 and ASP1052, amino acid residues of VEGF, were attached significantly to compound $9 \mathrm{~d}$ as the main providers of the inhibition interaction [Fig. 10a-d]. Through the in silico study, it was proved that ARG842, ASN923 and ASP1052 are the most preferred residues in the inhibitor binding reaction and the conclusion that the interaction energy does not include a contribution from the water or the expanded protein structure was supported. A list of hydrogen bond interactions between the protein and the active site was generated. The 
a)
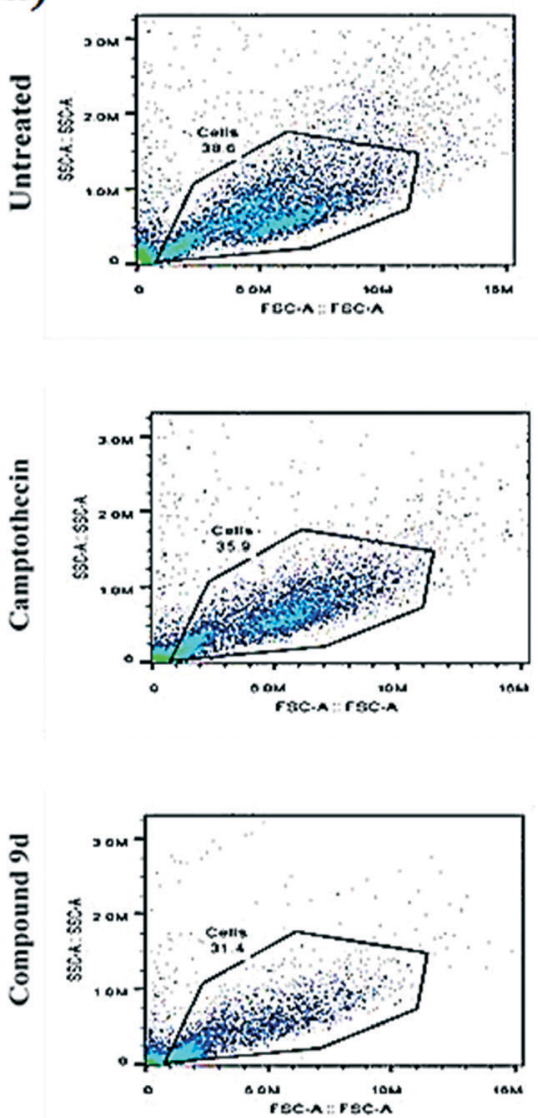
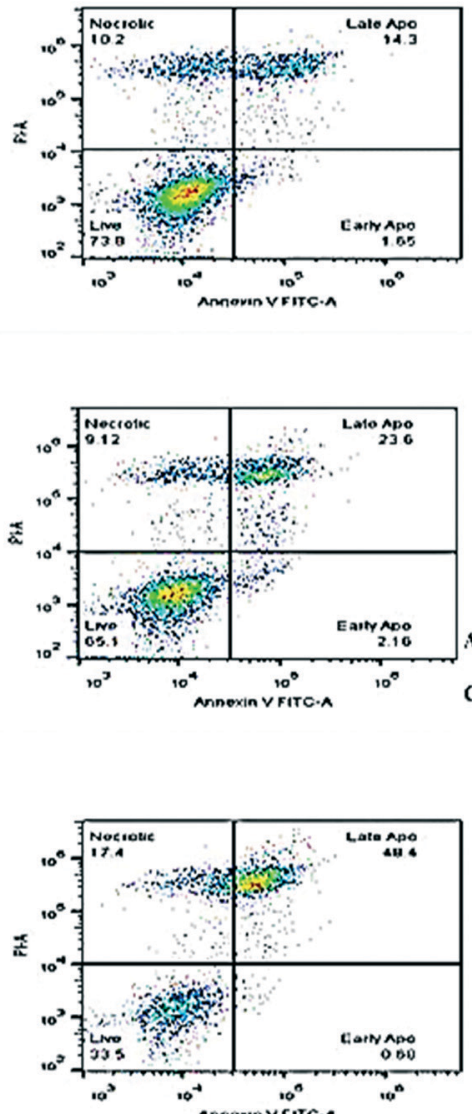

b)

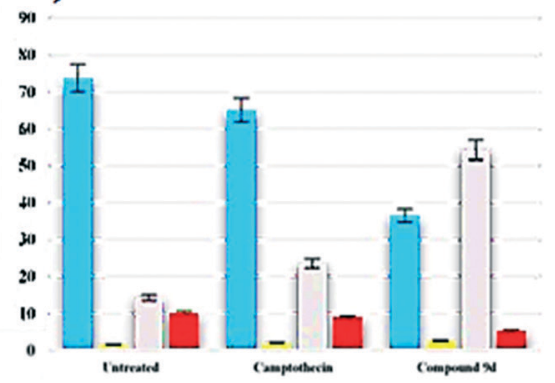

c)

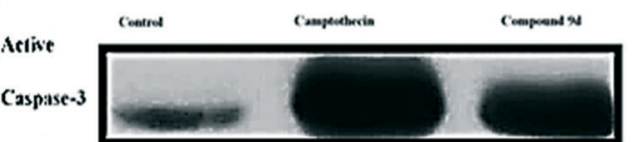

Bactin

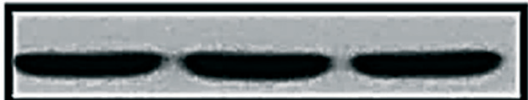

Fig. 7 Compound 9d promotes apoptotic cell death. FACS analysis showing the increased number of apoptotic cells in compound 9d-treated A549 cells. a) The sample of treated cells contained $0.68 \%$ of cells in early apoptosis and $48.4 \%$ of cells in late apoptosis. b) Graphical representation percentage of cells undergoing apoptosis. c) Compound 9d promotes apoptotic cell death by caspase-3 activation. The molecular basis of compound $9 \mathrm{~d}$ in exhibiting tumor regression was analyzed by immunoblot. Statistically significant values are expressed as $* p<0.05$ and $* * p<0.01$.
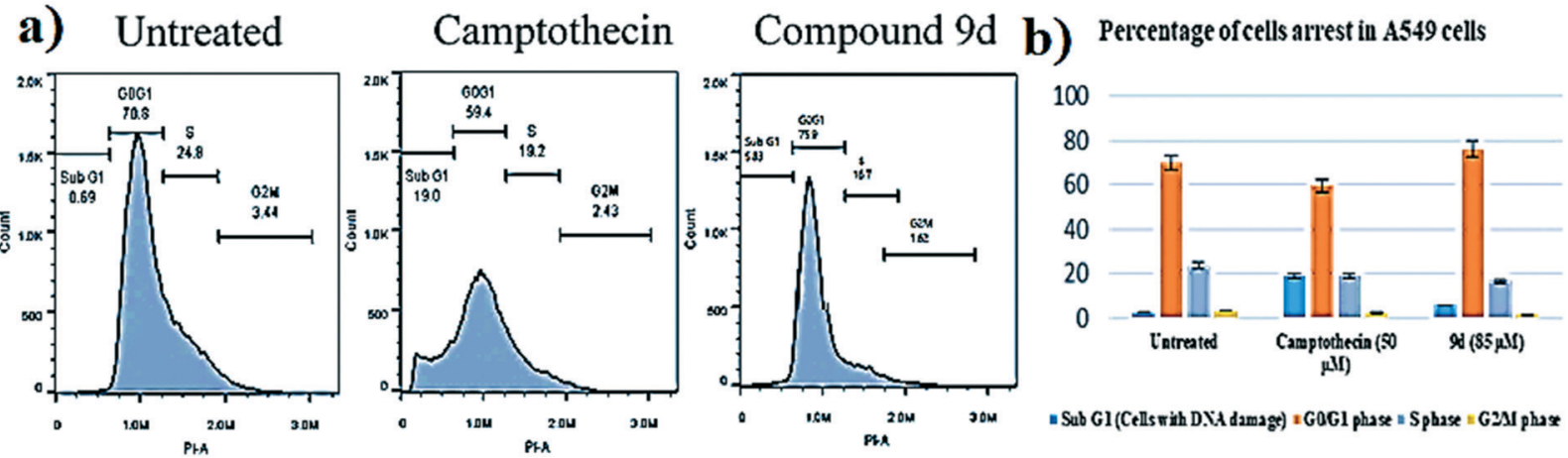

Fig. 8 a) Cell cycle arrest in the G2 phase was observed upon treatment with compound $9 \mathrm{~d}(85 \mu \mathrm{M})$ based on an observed increase in the percentage of cells in the G0/G1 gate. b) Graphical representation of the percentage of cells in the G0/G1, G2/M and S-phases of the cell cycle. Statistically significant values are expressed as $* p<0.05$ and $* * p<0.01$.

VEGF structure was further applied in protein-ligand modeling studies. Positively connected with receptor binding, docking in the VEGF protein plays a crucial role in sustaining a functional conformation. In this study, the interactions between the VEGF and the inhibitors are of great use in revealing and understanding the possible mechanism of inhibitor binding. In the VEGF structure, just as in other biological molecules, it is apparent that hydrogen bonds play a significant role. ARG842, ASN923 and ASP1052 are important for strong hydrogen bonding interactions with inhibitors.

It is obvious that molecule 9d is the most likely inhibitor and that ARG842, ASN923 and ASP1052 residues are involved 
Table 2 The dock score results of $N^{\prime}$-(2-(2-chloro-6-fluoro-4-(4-methylbenzoyl)phenoxy)acetyl)-1-methyl-1H-imidazole-4-carbohydrazide with VEGFr [PDB code: VEGFr (2xir:A)]

\begin{tabular}{|c|c|c|c|c|c|c|c|}
\hline Conformation & $\begin{array}{l}\text { Binding energy } \\
\left(\mathrm{kJ} \mathrm{mol}^{-1}\right)\end{array}$ & $\begin{array}{l}\text { Ligand } \\
\text { efficiency }\end{array}$ & $\begin{array}{l}\text { Inhibition } \\
\text { constant }\end{array}$ & $\begin{array}{l}\text { vdW }+ \text { H-bond }+ \\
\text { desolv energy }\end{array}$ & No. of $\mathrm{H}$ - bonds & Bonding residues & $\begin{array}{l}\text { Bond } \\
\text { length }(\AA)\end{array}$ \\
\hline \multirow{2}{*}{$\begin{array}{l}\text { S1 } \\
\text { S2 }\end{array}$} & -6.01 & -0.19 & 39.35 & -8.77 & - & - & 1.991 \\
\hline & -7.66 & -0.24 & 2.43 & -10.14 & 2 & 2xir:A:ASP1052:HN:Lig:LIG1:O: & 1.931 \\
\hline S3 & -5.8 & -0.18 & 35.76 & -8.47 & 1 & 2xir:A:ASP875:O:Lig:LIG1:H: & 2.197 \\
\hline S4 & -4.84 & -0.15 & 285.4 & -7.52 & - & - & - \\
\hline \multirow[t]{3}{*}{ S6 } & \multirow[t]{3}{*}{-6.73} & \multirow[t]{3}{*}{-0.21} & \multirow[t]{3}{*}{11.66} & \multirow[t]{3}{*}{-9.25} & \multirow[t]{3}{*}{3} & 2xir:A:ASN923:HN:Lig:LIG1:O: & 1.773 \\
\hline & & & & & & 2xir:A:ASN923:HD21:Lig:LIG1:O: & 1.914 \\
\hline & & & & & & 2xir:A:ASP1052:HN:Lig:LIG1:O: & 1.869 \\
\hline S7 & -5.93 & -0.19 & 45.13 & -8.61 & 1 & 2xir:A:ARG1027:HH22:Lig:LIG1:O: & 2.009 \\
\hline S8 & -5.48 & -0.17 & 95.71 & -8.23 & - & - & - \\
\hline S9 & -5.86 & -0.18 & 50.94 & -8.15 & 2 & 2xir:A:ASN923:HN:Lig:LIG1:O: & 1.675 \\
\hline
\end{tabular}

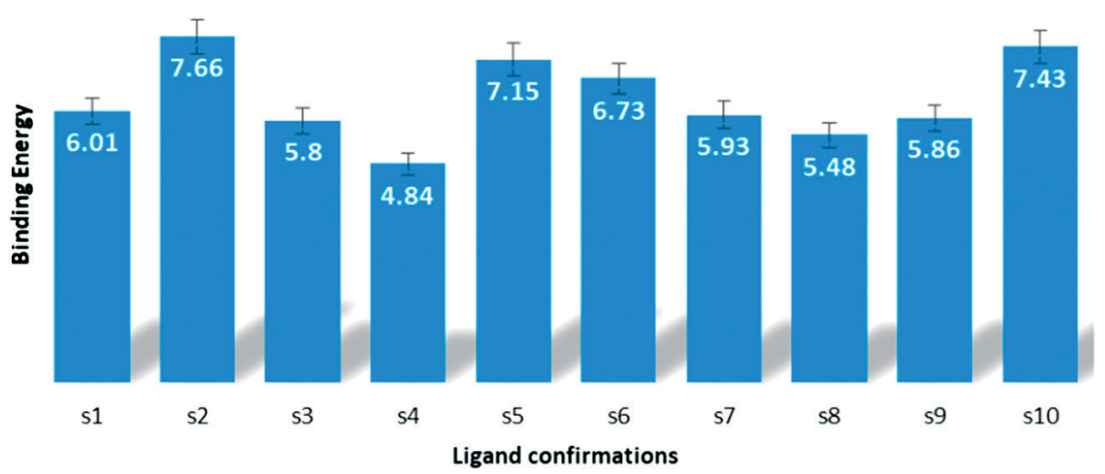

Fig. 9 Compound 9d showed minimum binding energy with rVEGF at the conformation S2 with the lowest binding energy of $-7.66 \mathrm{~kJ}$ mol ${ }^{-1}$; statistically significant values are expressed as $* p<0.05$ and $* * p<0.01$

in inhibitor binding and they form hydrogen bonds with the inhibitors. It should be taken into consideration that ARG842, ASN923 and ASP1052 are vital for receptor binding or preserving the hydrophobicity of the inhibitor binding pocket.

\section{Conclusion}

Through the current study, two series of novel benzophenone analogues containing imidazole (9a-d) and pyrone nuclei (10a-d) were synthesized. From the structure-activity relationship of these compounds, it was revealed that compound 9d, with methyl, chloro and fluoro groups in the benzophenone moiety, showed an anti-angiogenesis effect against A549, HeLa and MCF-7 cell lines with IC $_{50}$ of $9.1 \pm 0.5,10.4 \pm 2.1$ and $9.4 \pm 0.9 \mu \mathrm{M}$, respectively, and it was selected as the lead compound within this series. The results observed in the CAM models for the inhibition of neovascularization and tumor growth strongly supported our hypothesis. Compound 9d interacts with rVEGF by hydrogen bonds in silico, thereby down-regulating the VEGF expression in angiogenesis. Further, compound 9d has the potency to exhibit prolonged activity against cancer progression through cell cycle arrest at the G2/M phase, which may be mediated by the interaction of compound 9d with VEGF-A, as verified by a cell cycle analysis study and immunoblot. Therefore, in conclusion, we can state that compound 9d plays a crucial role through an angiopreventive effect and that it can be applied in various fields related to cancer therapeutics [Fig. 11].

\section{Materials and methods}

\subsection{Experimental section}

The chemicals required for the synthesis of the title compounds 9a-d and 10a-d were procured from Sigma Aldrich Chemical Co. The completion of the reaction was checked by thin layer chromatography (TLC), which was performed on aluminum backed silica plates and the spots were detected by exposure to a UV-lamp at $\lambda=254 \mathrm{~nm}$. Melting points and boiling points were measured on a Chemiline microcontroller-based 
a)

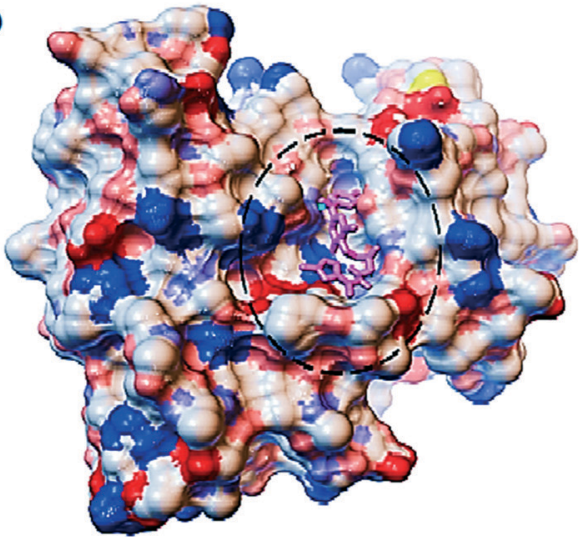

c)

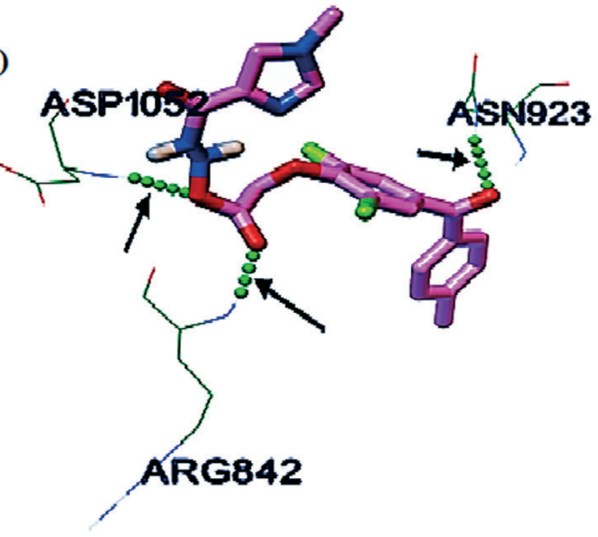

b)
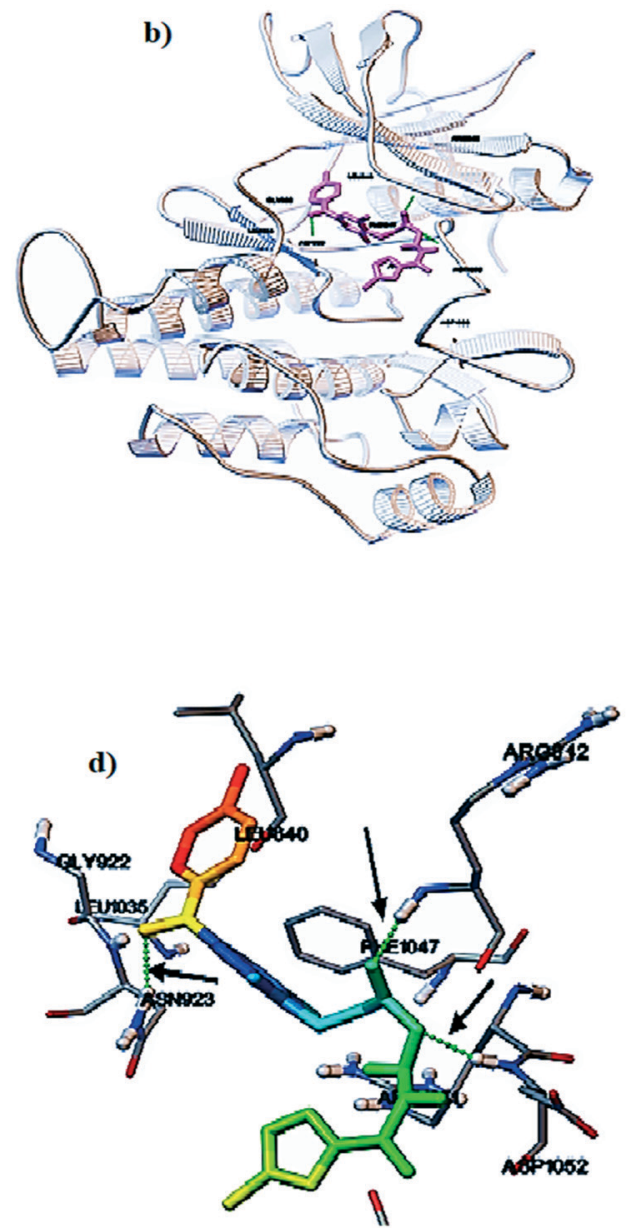

Fig. 10 In silico interaction of compound 9d VEGFr as the basis for cancer regression. a) Enfolding of molecules $9 \mathrm{~d}$ in the active site pocket of VEGFr complexes. b) Ribbon models of the $V_{E G F}$ catalytic domain and ligand molecules in compound $9 d$ complexes. c) Hydrogen bond interaction of ligand molecule compound $9 \mathrm{~d}$ with VEGFr. d) 3D interaction analysis of compound $9 \mathrm{~d}$ with VEGFr.
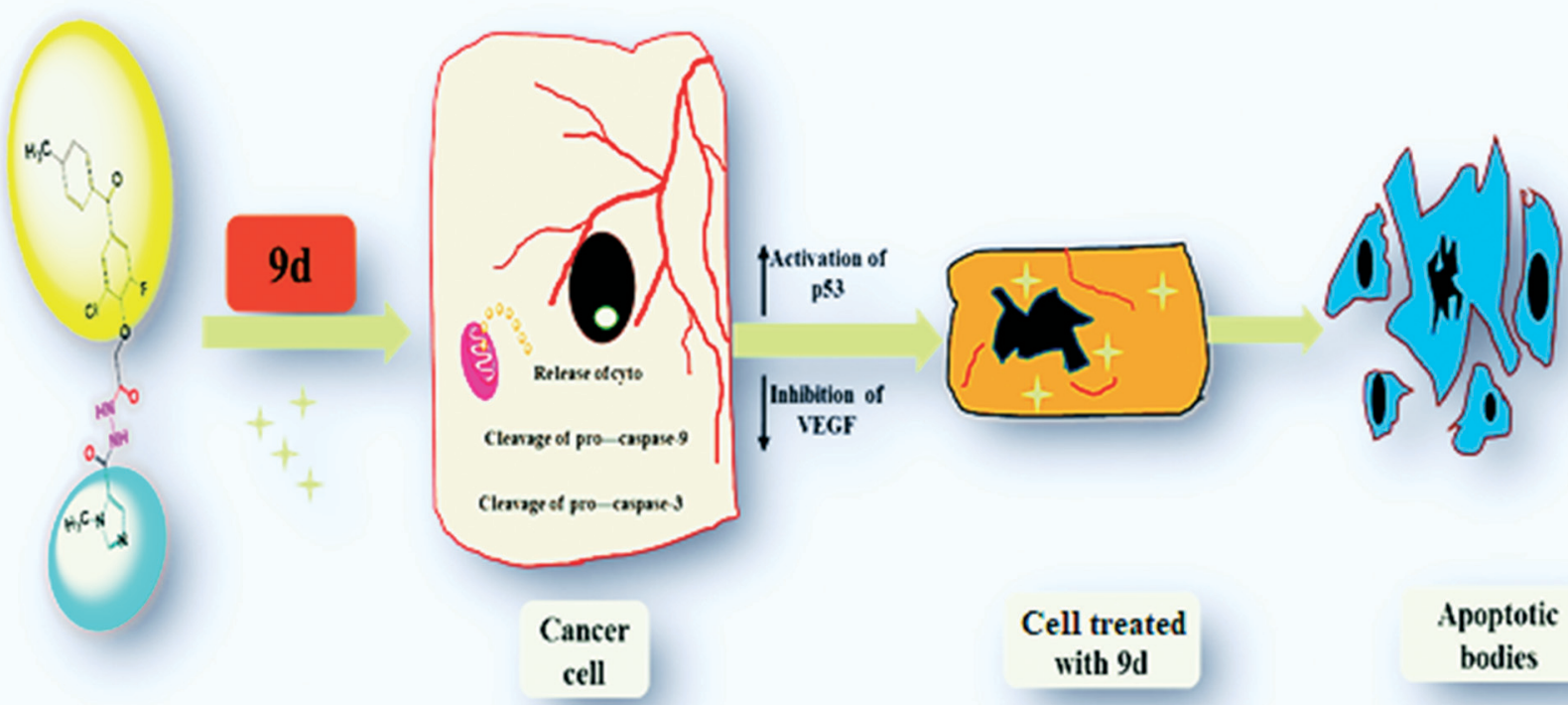
Cell treated with 9d

Apoptotic bodies

Fig. 11 Schematic representation of compound 9d exhibiting angiogenesis inhibition and induced apoptosis. 
melting point/boiling point Cl725 apparatus with a digital thermometer. IR spectra were recorded on the Agilent Technologies, Cary 630 FTIR spectrometer; ${ }^{1} \mathrm{H}$ and ${ }^{13} \mathrm{C}$ NMR spectra were recorded on a VNMRS-400 Agilent-NMR spectrophotometer. The mass spectra were obtained with a VG70-70H spectrometer and the elemental analysis $(\mathrm{C}, \mathrm{H}$, and $\mathrm{N})$ was performed on an ElementarVario EL III elemental analyzer. The results of the elemental analyses are within $\pm 0.4 \%$ of the theoretical values.

Cell lines, such as A549, HeLa, MCF-7 and normal NIH3T3 cells, were procured from NCCS, Pune, India. DMEM, sodium carbonate, fetal bovine serum (FBS), and MTT were obtained from Sigma Aldrich, USA. All cell culture materials were from Eppendorf, Germany. Penicillin-streptomycin was obtained from Sigma-Aldrich (USA). All photographs were taken using a Canon PowerShot SX500 IS camera.

\subsection{Chemistry: Plan of the synthesis}

Synthesis of novel benzophenone analogues $\mathbf{9 a - d}$ and 10a-d was accomplished according to the steps illustrated in Scheme 1. First, substituted phenols $\mathbf{1 a}-\mathbf{b}$ on reaction with substituted benzoyl chlorides $2 \mathbf{a}-\mathbf{d}$ in the presence of trimethylamine (TEA) gave substituted phenyl benzoates 3a-d. Compounds 3a-d on subjection to Fries rearrangement afforded substituted diaryl methanones, commonly known as hydroxy benzophenones $\mathbf{4 a - d}$. Then (2-aroyl-4-methylphenoxy) acetates $\mathbf{5 a}-\mathbf{d}$ were achieved in excellent yield by reacting compounds $\mathbf{4 a}-\mathbf{d}$ with ethyl bromoacetate in the presence of anhydrous potassium carbonate and dry acetone. Further, compounds 5a-d on treatment with $99 \%$ hydrazine hydrate gave different hydrazides 6a-d. Finally, compounds 6a-d on coupling with 1-methyl-1 $H$-imidazole-4-carboxylic acid (7) and separately with 2-oxo-2H-pyrone-5-carboxylic acid (8) in the presence of $O$-(benzotriazol-1-yl)- $N, N, N^{\prime}, N^{\prime}$-tetra methyl uranium tetra fluoro borate (TBTU) and lutidine as a coupling agent furnished the title compounds 9d and 10d in excellent yield.

4.2.1. General procedure for the synthesis of benzoic acid phenyl ester (3a-d). Substituted phenyl benzoates 3a-d were synthesized by dissolving substituted phenol $\mathbf{1 a}-\mathbf{b}$ and TEA $(0.45 \mathrm{~mol})$ in dichloro methane (DCM). Then the reaction mixture was cooled to $0{ }^{\circ} \mathrm{C}$. Then a solution of substituted benzoyl chloride $2 \mathrm{a}-\mathrm{d}(0.23 \mathrm{~mol})$ in DCM was slowly added to the reaction mixture and stirred for $5 \mathrm{~h}$ and the completion of the reaction was monitored by TLC using 4:1 $n$-hexane: ethyl acetate solvent mixture. Then the reaction mass was diluted with DCM $(100 \mathrm{ml})$ and washed with $10 \%$ sodium hydroxide solution $(3 \times 40 \mathrm{ml})$, followed by water $(3 \times 30$ $\mathrm{ml}$ ). The organic layer was dried over anhydrous sodium sulphate and the solid obtained after evaporation of the solvent was recrystallized from ethanol to give compounds 3a-d.

4.2.1.1. Phenyl benzoate (3a). Yield: $86 \%$; M.P. $52-54{ }^{\circ} \mathrm{C}$; FT-IR (KBr, $\left.v_{\max } \mathrm{cm}^{-1}\right): 1738(\mathrm{C}=\mathrm{O}), 1130(\mathrm{C}-\mathrm{O}), 722$ (Ar bending); ${ }^{1} \mathrm{H}$ NMR (DMSO-d $\mathrm{d}_{6}$ ): 7.12-8.41 (m, 10H, Ar-H); ${ }^{13} \mathrm{C}$ NMR (DMSO-d ${ }_{6}$ ) $\delta: 121.73,126.02,128.55,129.34,130.41$, 133.92, 149.50, 165.23; LC-MS m/z: $198(\mathrm{M}+)$ peak showed that $\mathrm{m} / \mathrm{z}$ is equivalent to molecular weight. Anal. calcd. for $\mathrm{C}_{13} \mathrm{H}_{10} \mathrm{O}_{2}$ : C, 77.93; H, 5.09. Found: C, 77.90; H, 5.04\%.

4.2.1.2. 2-Fluoro-6-chloro phenyl-4-fluoro benzoate (3b). Yield: 94\%; M.P. $54-56{ }^{\circ} \mathrm{C}$; FT-IR (KBr, $\left.v_{\max } \mathrm{cm}^{-1}\right): 1740$ $\left(\mathrm{C}=\mathrm{O}\right.$ ), 1150 (C-O), 722 (Ar bending); ${ }^{1} \mathrm{H}$ NMR (DMSO-d 6 ) $\delta$ : 6.94-8.28 (m, 7H, Ar-H); ${ }^{13} \mathrm{C}$ NMR (DMSO-d $\left.{ }_{6}\right) \delta:$ 114.03, 115.46, 125.92, 127.23, 128.55, 129.34, 131.41, 132.02, 140.53, 161.03, 165.31, 16 817; LC-MS m/z $268(\mathrm{M}+), 270(\mathrm{M}+2)$. Anal. calcd. for $\mathrm{C}_{13} \mathrm{H}_{7} \mathrm{ClF}_{2} \mathrm{O}_{2}$ : C, 58.12; H, 2.63. Found: C, 58.22 ; H, 2.43\%.

4.2.1.3. 2-Fluoro-6-chloro phenyl-4-chloro benzoate (3c). Yield: 95\%; M.P. $55-57{ }^{\circ} \mathrm{C}$; FT-IR (KBr, $\left.v_{\max } \mathrm{cm}^{-1}\right): 1750$ $(\mathrm{C}=\mathrm{O}), 1145$ (C-O), 722 (Ar bending); ${ }^{1} \mathrm{H}$ NMR (DMSO-d 6 ) $\delta$ : 6.92-8.12 (m, 7H, Ar-H); ${ }^{13} \mathrm{C}$ NMR (DMSO-d $\left.{ }_{6}\right) \delta:$ 114.03, $127.32,128.13,129.15,131.04,131.71,139.52,140.53$, 161.03165.23; LC-MS m/z $285(\mathrm{M}+), 287(\mathbf{M}+2), 289(\mathrm{M}+4)$. Anal. calcd. forC ${ }_{13} \mathrm{H}_{7} \mathrm{Cl}_{2} \mathrm{FO}_{2}$ : C, 54.77; H, 2.47. Found: C, 54.57; H, 2.33\%.

4.2.1.4. 2-Fluoro-6-chloro phenyl-4-methyl benzoate (3d). Yield: 96\%; M.P. $62-63{ }^{\circ} \mathrm{C}$; FT-IR (KBr, $\left.v_{\max } \mathrm{cm}^{-1}\right): 1780(\mathrm{C}=\mathrm{O})$ 1138 (C-O), 722 (Ar bending); ${ }^{1} \mathrm{H}$ NMR (DMSO-d ${ }_{6}$ ): $\delta 2.3$ (s, 3H, CH3), 7.38-8.07 (m, 7H, Ar-H); ${ }^{13} \mathrm{C}$ NMR (DMSO-d 6 ) $\delta: 21.34$, $114.05,127.32,128.13,130.24,131.64,140.51,143.62$, 161.03165.33; LC-MS $m / z 264(\mathrm{M}+), 266(\mathrm{M}+2)$. Anal. calcd. for $\mathrm{C}_{14} \mathrm{H}_{10} \mathrm{ClFO}_{2}$ : C, 63.53; H, 3.81. Found: C, 63.59; H, 3.79\%.

4.2.2. General procedure for the synthesis of 4-hydroxy benzophenones $(\mathbf{4 a - d})$. Substituted 4-hydroxy benzophenones 4a-d were synthesized by Fries rearrangement. Compounds 3a-d $(0.065 \mathrm{~mol})$ were blended with aluminium chloride $(0.128 \mathrm{~mol})$ and the mixture was heated to $150{ }^{\circ} \mathrm{C}$. This temperature was maintained for $3 \mathrm{~h}$ and the completion of the reaction was monitored by TLC using 4:1 $n$-hexane:ethyl acetate solvent mixture. Then the reaction mixture was cooled to room temperature and quenched with $7 \mathrm{~N}$ hydrochloric acid and ice water. The reaction mixture was stirred for about $2 \mathrm{~h}$. The solid obtained was filtered and recrystallized with methanol to obtain the desired compounds $4 a-d$.

4.2.2.1. (4-Hydroxyphenyl)(phenyl)methanone (4a). Yield: 61\%; M.P. $146-147{ }^{\circ} \mathrm{C}$; FT-IR (KBr, $\left.v_{\max } \mathrm{cm}^{-1}\right)$ : 1671 (C=O), 3545-3635 (O-H); ${ }^{1} \mathrm{H}$ NMR (DMSO-d $\left.{ }_{6}\right) \delta: 6.81-7.81(\mathrm{~m}, 9 \mathrm{H}$, $\mathrm{Ar}-\mathrm{H}), 9.68(\mathrm{~s}, 1 \mathrm{H}, \mathrm{OH}) ;{ }^{13} \mathrm{C}$ NMR $\left(\mathrm{DMSO}^{\mathrm{d}} \mathrm{d}_{6}\right) \delta:$ 116.11, 128.42, 130.01, 130.02, 131.43, 131.74, 132.51, 138.41, 162.03, 194.53; LC-MS $m / z 198(\mathrm{M}+)$. Anal. calcd. for $\mathrm{C}_{13} \mathrm{H}_{10} \mathrm{O}_{2}$ : C, 78.72; H, 5.08. Found: C, 78.69; H, 5.06\%.

4.2.2.2. (3-Chloro-5-fluoro-4-hydroxyphenyl)(4-fluorophenyl)methanone (4b). Yield: 61\%; M.P. 148-149 ${ }^{\circ} \mathrm{C}$; FT-IR (KBr, $\left.v_{\max } \mathrm{cm}^{-1}\right): 1671(\mathrm{C}=\mathrm{O}), 3545-3635(-\mathrm{OH}) ;{ }^{1} \mathrm{H}$ NMR (DMSO$\left.\mathrm{d}_{6}\right) \delta: 7.36-7.82(\mathrm{~m}, 6 \mathrm{H}, \mathrm{Ar}-\mathrm{H}), 11.64(\mathrm{bs}, 1 \mathrm{H}, \mathrm{OH}) ;{ }^{13} \mathrm{C} \mathrm{NMR}$ $\left(\mathrm{DMSO}_{6}\right) \delta: 114.21,115.23,125.42,127.31,130.32,131.43$, 134.04, 135.51, 148.41, 154.81, 166.03, 194.33; LC-MS m/z 268 $(\mathrm{M}+)$ and $270(\mathrm{M}+2)$. Anal. calcd. for $\mathrm{C}_{13} \mathrm{H}_{7} \mathrm{ClF}_{2} \mathrm{O}_{2}: \mathrm{C}, 58.12$; $\mathrm{H}, 2.63$. Found: $\mathrm{C}, 58.21 ; \mathrm{H}, 2.52 \%$.

4.2.2.3. (3-Chloro-5-fluoro-4-hydroxyphenyl)(4-chlorophenyl)methanone (4c). Yield: 68\%; M.P. 167-169 ${ }^{\circ} \mathrm{C}$; FT-IR (KBr, $\left.v_{\max } \quad \mathrm{cm}^{-1}\right): 1660 \quad(\mathrm{C}=\mathrm{O}), \quad 3525-3625 \quad(-\mathrm{OH}) ;{ }^{1} \mathrm{H} \quad \mathrm{NMR}$ 
(DMSO-d $)_{6} \delta:$ 7.12-7.74 (m, 6H, Ar-H), $11.60(\mathrm{~s}, 1 \mathrm{H}, \mathrm{OH})$; ${ }^{13} \mathrm{C}$ NMR (DMSO-d $\left.{ }_{6}\right) \delta: 114.21,125.42,127.41,128.62$, $131.72,135.33,136.54,138.01,148.41,154.81,166.03$, 194.33; LC-MS $m / z 285(M+), 287(M+2)$ and $289(M+4)$. Anal. calcd. for $\mathrm{C}_{13} \mathrm{H}_{7} \mathrm{Cl}_{2} \mathrm{FO}_{2}$ : C, 54.77; H, 2.47. Found: C, $54.65 ; \mathrm{H}, 2.32 \%$.

4.2.2.4. (3-Chloro-5-fluoro-4-hydroxyphenyl)(4-methylphenyl)methanone (4d). Yield: 65\%; M.P. 182-183 ${ }^{\circ} \mathrm{C}$; FT-IR ( $\mathrm{KBr}$, $\left.v_{\max } \mathrm{cm}^{-1}\right)$ : $1635(\mathrm{C}=\mathrm{O}), 3430-3590(\mathrm{OH}) ;{ }^{1} \mathrm{H}$ NMR (DMSOd6) $\delta: 2.73\left(\mathrm{~s}, 3 \mathrm{H}, \mathrm{CH}_{3}\right), 7.15-7.68(\mathrm{~m}, 6 \mathrm{H}, \mathrm{Ar}-\mathrm{H}), 9.46(\mathrm{~s}, 1 \mathrm{H}$, $\mathrm{OH}) ;) ;{ }^{13} \mathrm{C}$ NMR (DMSO-d 6 ) $\delta: 21.13,114.21,125.52,127.41$, 128.62, 130.32, 142.23, 148.41, 154.81, 194.33; LC-MS m/z 265 $(\mathrm{M}+)$ and $267(\mathrm{M}+2)$. Anal. calcd. for $\mathrm{C}_{14} \mathrm{H}_{10} \mathrm{ClFO}_{2}$ : C, 63.53; H, 3.81; Cl, 13.39; F, 7.18. Found: C, 63.55; H, 3.83; Cl, 13.41; F, $7.21 \%$.

4.2.3. General procedure for the synthesis of (4-benzoylphenoxy)-acetic acid ethyl esters (5a-d). To a solution of compounds 4 a-d $(0.036 \mathrm{~mol})$ in dry acetone $(70 \mathrm{ml})$, potassium carbonate $(0.078 \mathrm{~mol})$ and ethyl bromoacetate $(0.057 \mathrm{~mol})$ were added and the reaction mass was heated to $60^{\circ} \mathrm{C}$ for $4^{-}$ $6 \mathrm{~h}$, The progress of the reactions was monitored by TLC using 2:1 n-hexane: ethyl acetate solvent mixture. The reaction mixture was cooled and the solvent was removed by distillation. The residual mass was triturated with cold water to remove potassium carbonate, and extracted with ether $(3 \times$ $50 \mathrm{ml}$ ). The ether layer was washed with $10 \%$ sodium hydroxide solution $(3 \times 50 \mathrm{ml})$ followed by water $(3 \times 30 \mathrm{ml})$, dried over anhydrous sodium sulphate and evaporated to dryness to obtain crude solid, which, on recrystallization with ethanol afforded the desired compounds 5a-d.

4.2.3.1. (4-Benzoylphenoxy)acetic acid ethyl ester (5a). Yield: 90\%; M.P. 47-49 ${ }^{\circ} \mathrm{C}$; FT-IR (KBr, $\left.v_{\max } \mathrm{cm}^{-1}\right)$ : $1660(\mathrm{C}=\mathrm{O})$, 1730 (ester, $\mathrm{C}=\mathrm{O}), 1130(\mathrm{C}-\mathrm{O}) ;{ }^{1} \mathrm{H}$ NMR $\left(\mathrm{DMSO}^{\mathrm{d}} \mathrm{d}_{6}\right) \delta: 1.28(\mathrm{t}$, $3 \mathrm{H}, \mathrm{CH}_{3}$ of ester), 4.21 (q, $J=6 \mathrm{~Hz}, 2 \mathrm{H}, \mathrm{CH}_{2}$ of ester), 5.03 (s, $2 \mathrm{H}, \mathrm{CH}_{2}$ ), 6.92-7.83 (m, 9H, Ar-H); ${ }^{13} \mathrm{C}$ NMR (DMSO-d 6 ) $\delta$ : 61.33, 65.31, 114.03, 128.43, 130.02, 130.72.41, 131.37, 138.52, 161.93, 169.41, 194.43; LC-MS: m/z: 285 (M+). Anal. calcd. for $\mathrm{C}_{17} \mathrm{H}_{16} \mathrm{O}_{4}: \mathrm{C}, 71.82 ; \mathrm{H}$, 5.67. Found: C, 71.85; $\mathrm{H}$, $5.69 \%$.

4.2.3.2. (4-Fluorobenzoyl-2-chloro-6-fluorophenoxy)acetic acid ethyl ester (5b). Yield: 85\%; M.P. 50-52 ${ }^{\circ} \mathrm{C}$; FT-IR (KBr, $\left.v_{\max } \mathrm{cm}^{-1}\right): 1660(\mathrm{C}=\mathrm{O}), 1730$ (ester, $\left.\mathrm{C}=\mathrm{O}\right), 1135(\mathrm{C}-\mathrm{O}) ;{ }^{1} \mathrm{H}$ NMR (DMSO-d ${ }_{6}$ ) $\delta: 1.27\left(\mathrm{t}, 3 \mathrm{H}, \mathrm{CH}_{3}\right.$ of ester), 4.21 (q, $J=6$ $\mathrm{Hz}, 2 \mathrm{H}, \mathrm{CH}_{2}$ of ester), $5.03\left(\mathrm{~s}, 2 \mathrm{H}, \mathrm{CH}_{2}\right), 7.58-7.77(\mathrm{~m}, 6 \mathrm{H}$, $\mathrm{Ar}-\mathrm{H}) ;{ }^{13} \mathrm{C}$ NMR (DMSO-d $\left.{ }_{6}\right) \delta: 61.33,64.95,114.03,115.24$, 123.94, 126.93, 133.52, 134.12.41, 135.37, 153.52, 166.93, 169.41, 194.43; LC-MS: $m / z: 354(\mathrm{M}+)$ and $356(\mathrm{M}+2)$. Anal. calcd. for $\mathrm{C}_{17} \mathrm{H}_{13} \mathrm{ClF}_{2} \mathrm{O}_{4}$ : C, 57.56; $\mathrm{H}, 3.69$. Found: $\mathrm{C}, 57.41 ; \mathrm{H}$, $3.52 \%$.

4.2.3.3. [2-Chloro-4-(4-chloro-benzoyl)-6-fluoro-phenoxy]acetic acid ethyl ester (5c). Yield: 83\%; M.P. 54-56 ${ }^{\circ} \mathrm{C}$; FT-IR $\left(\mathrm{KBr}, v_{\max } \mathrm{cm}^{-1}\right)$ : $1650(\mathrm{C}=\mathrm{O}), 1740$ (ester, $\left.\mathrm{C}=\mathrm{O}\right), 1135$ (CO); ${ }^{1} \mathrm{H}$ NMR (DMSO-d $\left.{ }_{6}\right) \delta: 1.27\left(\mathrm{t}, J=7 \mathrm{~Hz}, 3 \mathrm{H}, \mathrm{CH}_{3}\right.$ of ester), $4.12\left(\mathrm{q}, J=6 \mathrm{~Hz}, 2 \mathrm{H}, \mathrm{CH}_{2}\right.$ of ester), $4.92\left(\mathrm{~s}, 2 \mathrm{H}, \mathrm{CH}_{2}\right), 7.59-$ $7.75(\mathrm{~m}, 6 \mathrm{H}, \mathrm{Ar}-\mathrm{H}) ;{ }^{13} \mathrm{C}$ NMR $\left(\mathrm{DMSO}_{6} \mathrm{~d}_{6}\right) \delta: 61.33,64.95$, $114.03,115.24,123.94,126.93,133.52,134.12 .41,135.37$,
153.52, 166.93, 169.41, 194.43; LC-MS: $m / z: 371$ (M+), 373 (M $+2)$ and $375(M+4)$. Anal. calcd. for $\mathrm{C}_{17} \mathrm{H}_{13} \mathrm{Cl}_{2} \mathrm{FO}_{4}: \mathrm{C}, 55.01$; $\mathrm{H}, 3.53$. Found: C, 55.19; $\mathrm{H}, 3.41 \%$.

4.2.3.4. (4-Methylbenzoyl-2-chloro-6-fluorophenoxy)acetic acid ethyl ester (5d). Yield: 83\%; M.P. 62-63 ${ }^{\circ} \mathrm{C}$; FT-IR (KBr, $\left.v_{\max } \mathrm{cm}^{-1}\right): 1650(\mathrm{C}=\mathrm{O}), 1740$ (ester, $\left.\mathrm{C}=\mathrm{O}\right), 1125(\mathrm{C}-\mathrm{O}) ;{ }^{1} \mathrm{H}$ NMR (DMSO-d $\left.)_{6}\right) \delta: 1.25\left(\mathrm{t}, J=7 \mathrm{~Hz}, 3 \mathrm{H}, \mathrm{CH}_{3}\right.$ of ester), $2.32(\mathrm{~s}$, $\left.3 \mathrm{H}, \mathrm{CH}_{3}\right), 4.19$ (q, $J=6 \mathrm{~Hz}, 2 \mathrm{H}, \mathrm{CH}_{2}$ of ester) $5.02(\mathrm{~s}, 2 \mathrm{H}$, $\left.\mathrm{CH}_{2}\right), 7.24-7.66(\mathrm{~m}, 6 \mathrm{H}, \mathrm{Ar}-\mathrm{H}) ;{ }^{13} \mathrm{C}$ NMR $\left(\mathrm{DMSO}_{6}\right) \delta: 21.31$, $61.33,64.95,114.03,123.94,126.21,127.75,130.25,135.37$, 142.11, 153.32, 169.41, 194.43; LC-MS: $m / z: 351(\mathrm{M}+), 352(\mathrm{M}$ +2 ). Anal. calcd. for $\mathrm{C}_{18} \mathrm{H}_{16} \mathrm{ClFO}_{4}$ : C, 61.64; H, 4.60; Cl, 10.11; F, 5.42. Found: C, 61.66; H, 4.63; Cl, 10.13; F, 5.44\%.

4.2.4. General procedure for the synthesis of 2-(4-benzoylphenoxy)acetohydrazides (6a-d). Hydrazine hydrate (0.018 $\mathrm{mol})$ was added to a solution of compounds $5 \mathrm{a}-\mathrm{d}(0.018 \mathrm{~mol})$ in ethanol $(30 \mathrm{ml})$ and continuously stirred for $3 \mathrm{~h}$ at room temperature. The completion of the reaction was monitored by TLC using 2:1 chloroform: ethyl acetate as a mobile phase. After the separation of a white solid, it was quenched with water $(50 \mathrm{ml})$, filtered and washed with water $(50 \mathrm{ml})$. The solid was dried under vacuum and the product was recrystallized from ethanol to obtain compounds $6 \mathbf{a}-\mathbf{d}$ in good yield.

4.2.4.1. 2-(4-Benzoylphenoxy)acetohydrazide (6a). Yield: 76\%; M.P. 107-109 ${ }^{\circ}$ C; FT-IR ( $\left.\mathrm{KBr}, v_{\max } \mathrm{cm}^{-1}\right): 1610(\mathrm{C}=\mathrm{O})$, 1645 (amide, $\mathrm{C}=\mathrm{O}), 3100-3205\left(\mathrm{NH}-\mathrm{NH}_{2}\right) ;{ }^{1} \mathrm{H}$ NMR (DMSO$\left.\mathrm{d}_{6}\right) \delta: 4.35\left(\mathrm{~s}, 2 \mathrm{H}, \mathrm{NH}_{2}\right), 4.89\left(\mathrm{~s}, 2 \mathrm{H}, \mathrm{OCH}_{2}\right), 7.01-8.86(\mathrm{~m}, 9 \mathrm{H}$, $\mathrm{Ar}-\mathrm{H}), 9.02$ (s, 1H, NH); ${ }^{13} \mathrm{C}$ NMR $\left(\mathrm{DMSO}_{6}\right) \delta: 66.25,114.11$, 128.44, 130.21, 131.05, 132.45, 138.37, 161.41, 166.31, 194.43; LC-MS $m / z 270(\mathrm{M}+)$. Anal. calcd. for $\mathrm{C}_{15} \mathrm{H}_{14} \mathrm{~N}_{2} \mathrm{O}_{3}$ : C, 66.66; $\mathrm{H}$, 5.22; N, 10.36. Found: C, 66.68; H, 5.24; N, 8.13\%.

4.2.4.2. [2-4(4-Fluoro)benzoyl-2-chloro-6-fluorophenoxy]acetohydrazide (6b). Yield: 79\%; M.P. 110-113 ${ }^{\circ} \mathrm{C}$; FT-IR (KBr, $\left.v_{\max } \mathrm{cm}^{-1}\right): 1620(\mathrm{C}=\mathrm{O}), 1645$ (amide, $\left.\mathrm{C}=\mathrm{O}\right), 3100-3205$ $\left(\mathrm{NH}-\mathrm{NH}_{2}\right) ;{ }^{1} \mathrm{H}$ NMR $\left(\mathrm{DMSO}_{-}\right) \delta: 4.35\left(\mathrm{~s}, 2 \mathrm{H}, \mathrm{NH}_{2}\right), 4.69(\mathrm{~s}$, $\left.2 \mathrm{H}, \mathrm{OCH}_{2}\right), 7.20-7.86(\mathrm{~m}, 6 \mathrm{H}, \mathrm{Ar}-\mathrm{H}), 9.32(\mathrm{~s}, 1 \mathrm{H}, \mathrm{NH}) ;{ }^{13} \mathrm{C}$ NMR (DMSO-d 6 ) $\delta: 65.95,114.31,123.85,126.93,133.45$, 134.01, 135.04, 153.41, 166.61, 194.43; LC-MS $m / z: 340(\mathrm{M}+)$ and $342(\mathrm{M}+2)$. Anal. calcd. for $\mathrm{C}_{15} \mathrm{H}_{11} \mathrm{ClF}_{2} \mathrm{~N}_{2} \mathrm{O}_{3}: \mathrm{C}, 52.88 ; \mathrm{H}$, 3.25; Cl, 10.41; F, 11.15; N, 8.22. Found: C, 52.75; H, 3.38\%.

4.2.4.3. 2-(2-Chloro-4-(4-chlorobenzoyl)-6-fluorophenoxy)acetohydrazide (6c). Yield: 79\%; M.P. $112-116{ }^{\circ} \mathrm{C}$; FT-IR $(\mathrm{KBr}$, $\left.v_{\text {max }} \mathrm{cm}^{-1}\right): 1610(\mathrm{C}=\mathrm{O}), 1645$ (amide, $\left.\mathrm{C}=\mathrm{O}\right), 3100-3205(\mathrm{NH}-$ $\mathrm{NH}_{2}$ ); ${ }^{1} \mathrm{H}$ NMR (DMSO-d $\left.{ }_{6}\right) \delta: 4.35\left(\mathrm{~s}, 2 \mathrm{H}, \mathrm{NH}_{2}\right), 4.83(\mathrm{~s}, 2 \mathrm{H}$, $\mathrm{OCH}_{2}$ ), 7.20-7.76 (m, 6H, Ar-H), 9.32 (s, 1H, NH); ${ }^{13} \mathrm{C}$ NMR $\left(\mathrm{DMSO}_{6}\right) \delta$ : 65.95, 114.31, 115.22, 123.85, 126.93, 133.45, 134.01, 135.04, 153.41, 166.61, 194.43; LC-MS m/z 357 (M+) and $359(\mathrm{M}+2)$. Anal. calcd. for $\mathrm{C}_{15} \mathrm{H}_{11} \mathrm{Cl}_{2} \mathrm{FN}_{2} \mathrm{O}_{3}: \mathrm{C}, 50.44 ; \mathrm{H}$, 3.10; Cl, 19.85; F, 5.32; N, 7.84. Found: C, 50.46; H, 3.13\%.

4.2.4.4. [2-4(4-Methyl)benzoyl-2-chloro-6-fluorophenoxy]acetohydrazide (6d). Yield: 79\%; M.P. 117-123 ${ }^{\circ} \mathrm{C}$; FT-IR (KBr, $\left.v_{\max } \mathrm{cm}^{-1}\right)$ : $1610(\mathrm{C}=\mathrm{O}), 1645$ (amide, $\left.\mathrm{C}=\mathrm{O}\right), 3100-3205$ $\left(\mathrm{NH}-\mathrm{NH}_{2}\right) ;{ }^{1} \mathrm{H}$ NMR $\left(\mathrm{DMSO}_{6}\right) \delta: 2.40\left(\mathrm{~s}, 2 \mathrm{H}, \mathrm{CH}_{3}\right), 4.31(\mathrm{~s}$, $\left.2 \mathrm{H}, \mathrm{NH}_{2}\right), 4.79\left(\mathrm{~s}, 2 \mathrm{H}, \mathrm{OCH}_{2}\right), 7.20-7.86(\mathrm{~m}, 6 \mathrm{H}, \mathrm{Ar}-\mathrm{H}), 9.32$ $(\mathrm{s}, 1 \mathrm{H}, \mathrm{NH}) ;{ }^{13} \mathrm{C}$ NMR (DMSO-d 6 ) $\delta: 21.34,65.95,114.31$, 
$123.85,126.93,128.73,130.22,135.45,142.21 .04,153.31$, 166.61, 194.43; LC-MS $m / z 336(\mathrm{M}+)$ and $338(\mathrm{M}+2)$. Anal. calcd. for $\mathrm{C}_{16} \mathrm{H}_{14} \mathrm{ClFN}_{2} \mathrm{O}_{3}$ : C, 57.07; $\mathrm{H}, 4.19 ; \mathrm{Cl}, 10.53 ; \mathrm{F}, 5.64$; N, 8.32. Found: C, 57.09; H, 4.22\%.

4.2.5. General procedure for the synthesis of 2-(4-benzoylphenoxy)aceto- $N \quad(N$-methyl imidazole)carbonyl hydrazides (9a-d). 2-(4-Benzoylphenoxy)acetohydrazides 6a-d $(0.0010 \mathrm{~mol})$ in dry DCM $(20 \mathrm{ml})$ were stirred at $25-30{ }^{\circ} \mathrm{C}$, and then lutidine $(0.0015 \mathrm{~mol})$ was added, followed by the addition of $\mathrm{N}$-methyl imidazole-4-carboxylic acid (7, 0.0010 $\mathrm{mol})$. The reaction mixture was stirred at the same temperature for 30 minutes, then cooled to $0-5{ }^{\circ} \mathrm{C}$ and TBTU $(0.0015$ $\mathrm{mol}$ ) was added and the temperature was maintained to $5{ }^{\circ} \mathrm{C}$ over a period of 30 minutes. The reaction mass was stirred overnight and monitored by TLC using chloroform:methanol $(9: 1)$ as the mobile phase. Then the solvent was evaporated at reduced pressure, quenched by the addition of crushed ice and the solid obtained was filtered, dried and recrystallized from ethanol to afford compounds $9 a-\mathbf{d}$ in good yield.

4.2.5.1. 2-(4-Benzoylphenoxy)aceto-N(N-methyl imidazole) carbonyl hydrazide (9a). Yield: 93\%; Purity > 96\% HPLC; M.P. 103-105 ${ }^{\circ} \mathrm{C}$; FT-IR $\left(\mathrm{KBr}, v_{\max } \mathrm{cm}^{-1}\right): 1650(\mathrm{C}=\mathrm{O}), 1678\left(-\mathrm{CH}_{2}-\right.$ $\mathrm{C}=\mathrm{O}), 1735(\mathrm{C}=\mathrm{O}), 3275-3360(\mathrm{NH}-\mathrm{NH})$; ${ }^{1} \mathrm{H}$ NMR (DMSO$\left.\mathrm{d}_{6}\right) \delta: 3.71\left(\mathrm{~s}, 3 \mathrm{H}, \mathrm{CH}_{3}\right), 4.86\left(\mathrm{~s}, 2 \mathrm{H}, \mathrm{OCH}_{2}\right), 6.91-8.08(\mathrm{~m}$, 11H, Ar-H), 9.89 (s,1H, NH), 10.39 (s, 1H, NH); ${ }^{13} \mathrm{C}$ NMR $\left(\right.$ DMSO-d $\left._{6}\right) \delta: 32.16,72.77,114.09,123.03,126.04,128.73$, 130.11, 130.59, 131.65, 132.18, 137.80, 140.21, 165.70, 167.34, 175.45, 187.38; LC-MS $m / z 379(\mathbf{M}+1)$ and $380(\mathbf{M}+2)$. Anal. calcd. for $\mathrm{C}_{20} \mathrm{H}_{18} \mathrm{~N}_{4} \mathrm{O}_{4}$ : C, 63.48; $\mathrm{H}, 4.79 ; \mathrm{N}, 14.81$, Found: $\mathrm{C}$, 63.46; H, 4.78; N, 14.82\%.

4.2.5.2. [2-4(4-Fluoro) benzoyl-2-chloro-6-fluorophenoxy]acetoN(N-methyl imidazole) carbonyl hydrazide (9b). Yield: 96\%; Purity > 87\% HPLC; M.P. $107-109{ }^{\circ} \mathrm{C}$; FT-IR (KBr, $\left.v_{\max } \mathrm{cm}^{-1}\right)$ : $1675(\mathrm{C}=\mathrm{O}), 1676\left(-\mathrm{CH}_{2}-\mathrm{C}=\mathrm{O}\right), 1755(\mathrm{C}=\mathrm{O}), 3275-3360$ $(\mathrm{NH}-\mathrm{NH}) ;{ }^{1} \mathrm{H}$ NMR (DMSO-d $\left.{ }_{6}\right) \delta: 3.71\left(\mathrm{~s}, 3 \mathrm{H}, \mathrm{CH}_{3}\right), 4.86(\mathrm{~s}$, 2H, $\mathrm{OCH}_{2}$ ), 6.91-8.05 (m, 8H, Ar-H), 9.87 (s, 1H, NH), 10.89 $(\mathrm{s}, 1 \mathrm{H}, \mathrm{NH}) ;{ }^{13} \mathrm{C}$ NMR (DMSO-d $) ~ \delta: ~ 29.16,77.07,115.21$, 116.03, 120.66, 120.72, 123.00, 126.46, 127.54, 131.29, 133.65, 133.18, 140.03, 148.44, 155.51, 168.41, 167.04, 173.95, 189.78; LC-MS $m / z 448(\mathrm{M}+)$ and $450(\mathrm{M}+2)$. Anal. calcd. for $\mathrm{C}_{20} \mathrm{H}_{15} \mathrm{ClF}_{2} \mathrm{~N}_{4} \mathrm{O}_{4}$ : C, 53.52; H, 3.37; Cl, 7.90; F, 8.47; N, 12.48, Found: C, 53.54; H, 3.35; N, 12.46\%.

4.2.5.3. [2-4(4-Chloro) benzoyl-2-chloro-6-fluorophenoxy]aceto$N$ (N-methyl imidazole) carbonyl hydrazide (9c). Yield: 85\%; Purity > 85\% HPLC; M.P. $106-108{ }^{\circ} \mathrm{C}$; FT-IR (KBr, $\left.v_{\max } \mathrm{cm}^{-1}\right)$ : $1680(\mathrm{C}=\mathrm{O}), 1679\left(-\mathrm{CH}_{2}-\mathrm{C}=\mathrm{O}\right), 1730(\mathrm{C}=\mathrm{O}), 3275-3360$ $(\mathrm{NH}-\mathrm{NH}) ;{ }^{1} \mathrm{H}$ NMR (DMSO-d 6 ) $\delta: 3.69\left(\mathrm{~s}, 3 \mathrm{H}, \mathrm{CH}_{3}\right), 4.86(\mathrm{~s}$, 2H, $\left.\mathrm{OCH}_{2}\right), 6.91-7.85(\mathrm{~m}, 8 \mathrm{H}, \mathrm{Ar}-\mathrm{H}), 9.88(\mathrm{~s}, 1 \mathrm{H}, \mathrm{NH}), 10.89$ $(\mathrm{s}, 1 \mathrm{H}, \mathrm{NH}) ;{ }^{13} \mathrm{C} \mathrm{NMR}\left(\mathrm{DMSO}_{6}\right) \delta$ : 28.16, 77.27, 116.79, 120.7, 123.66, 126.54, 128.51, 131.29, 133.65, 136.21, 137.50, 140.18, 148.44, 153.41, 167.01, 175.45, 194.78; LC-MS m/z 464 $(\mathrm{M}+)$ and $466(\mathrm{M}+2)$. Anal. calcd. for $\mathrm{C}_{20} \mathrm{H}_{15} \mathrm{Cl}_{2} \mathrm{FN}_{4} \mathrm{O}_{4}: \mathrm{C}$, 51.63; H, 3.25; Cl, 15.24; F, 4.08; N, 12.04, Found: C, 51.62; $\mathrm{H}, 3.24 ; \mathrm{N}, 12.02 \%$.

4.2.5.4. [2-4(4-Methyl) benzoyl-2-chloro-6-fluorophenoxy]acetoN(N-methyl imidazole) carbonyl hydrazide (9d). Yield: 89\%;
Purity > 85\% HPLC; M.P. $114-117{ }^{\circ} \mathrm{C}$; FT-IR $\left(\mathrm{KBr}, v_{\max } \mathrm{cm}^{-1}\right)$ : $1645(\mathrm{C}=\mathrm{O}), 1682\left(-\mathrm{CH}_{2}-\mathrm{C}=\mathrm{O}\right), 1740(\mathrm{C}=\mathrm{O}), 3275-3360$ $(\mathrm{NH}-\mathrm{NH}) ;{ }^{1} \mathrm{H}$ NMR (DMSO-d $\left.{ }_{6}\right) \delta: 2.41\left(\mathrm{~s}, 3 \mathrm{H}, \mathrm{Ar}-\mathrm{CH}_{3}\right), 3.71$ $\left(\mathrm{s}, 3 \mathrm{H}, \mathrm{CH}_{3}\right), 4.86\left(\mathrm{~s}, 2 \mathrm{H}, \mathrm{OCH}_{2}\right), 6.91-7.85(\mathrm{~m}, 8 \mathrm{H}, \mathrm{Ar}-\mathrm{H})$, 9.89 (1H, NH), $10.89(\mathrm{~s}, 1 \mathrm{H}, \mathrm{NH}) ;{ }^{13} \mathrm{C}$ NMR $\left(\mathrm{DMSO}^{-\mathrm{d}_{6}}\right) \delta$ : $26.55,25.55,77.93,116.26,120.08,123.84,126.61,127.13$, 128.35, 130.00, 133.12, 134.82, 141.43, 148.81, 153.13, 167.02, 170.22, 187.01; LC-MS $m / z 444(\mathrm{M}+)$ and $446(\mathrm{M}+2)$. Anal. calcd. for $\mathrm{C}_{21} \mathrm{H}_{18} \mathrm{ClFN}_{4} \mathrm{O}_{4}$ : C, 56.70; H, 4.08; Cl, 7.97; F, 4.27; $\mathrm{N}, 12.59$, Found: C, 56.68; H, 4.07; N, 12.58\%.

4.2.6. General procedure for the synthesis of 2-(4-benzoylphenoxy)aceto- $N$ (pyrone-2-one)carbonyl hydrazides (10a-d). Compounds 6a-d $(0.0010 \mathrm{~mol})$ in dry DCM $(20$ $\mathrm{ml})$ were stirred at $25-30{ }^{\circ} \mathrm{C}$, and then lutidine $(0.0015 \mathrm{~mol})$ was added dropwise, followed by the addition of $2-0 x-2 \mathrm{H}-$ pyrone-5-carboxylic acid $(8,0.0010 \mathrm{~mol})$. The reaction mixture was stirred at the same temperature for 30 minutes, then cooled to $0-5{ }^{\circ} \mathrm{C}$ and TBTU $(0.0015 \mathrm{~mol})$ was added, maintaining the temperature below $5{ }^{\circ} \mathrm{C}$ over a period of 30 minutes. The reaction mass was stirred overnight and monitored by TLC using chloroform : methanol (9:1) as the mobile phase. The solvent was evaporated at reduced pressure, quenched by the addition of crushed ice and the obtained solid was filtered, dried and recrystallized from ethanol to afford compounds 10a-d in good yield.

4.2.6.1. 2-(4-Benzoylphenoxy)aceto-N(pyrone-2-one)carbonyl hydrazide (10a). Yield: 81\%; Purity > 85\% HPLC;M.P. 112$115{ }^{\circ} \mathrm{C}$; FT-IR $\left(\mathrm{KBr}, v_{\max } \mathrm{cm}^{-1}\right): 1650(\mathrm{C}=\mathrm{O}), 1678\left(-\mathrm{CH}_{2}-\right.$ $\mathrm{C}=\mathrm{O}), 1725(\mathrm{C}=\mathrm{O}$ of pyrone e), 3275-3360 ( $\mathrm{NH}-\mathrm{NH}) ;{ }^{1} \mathrm{H}$ NMR (DMSO-d $\left.{ }_{6}\right) \delta: 4.86\left(\mathrm{~s}, 2 \mathrm{H}, \mathrm{OCH}_{2}\right), 6.31-8.65(\mathrm{~m}, 12 \mathrm{H}$, $\mathrm{Ar}-\mathrm{H}), 9.79$ (s, 1H, NH), 10.34 (s, 1H, NH); ${ }^{13} \mathrm{C}$ NMR (DMSO$\left.\mathrm{d}_{6}\right) \delta: 78.47,105.29,113.76,120.93,128.26,130.10,130.19$, $131.20,131.45,138.48,146.21,165.71,161.83,165.98$, 170.45, 187.38; LC-MS $m / z 392(\mathrm{M}+)$. Anal. calcd. for $\mathrm{C}_{21} \mathrm{H}_{16} \mathrm{~N}_{2} \mathrm{O}_{6}$ : C, 64.28; H, 4.11; N, 7.14, Found: C, 64.26; H, $4.09 ; \mathrm{N}, 7.12 \%$.

4.2.6.2. [2-4(4-Fluoro)benzoyl-2-chloro-6-fluorophenoxy]acetoN(pyrone-2-one)carbonyl hydrazide (10b). Yield: 72\%; Purity > 81\% HPLC; M.P. $116-119{ }^{\circ} \mathrm{C}$; FT-IR (KBr, $v_{\max } \mathrm{cm}^{-1}$ ): 1660 $(\mathrm{C}=\mathrm{O}), 1682$ (amide, $\mathrm{C}=\mathrm{O}), 1732(\mathrm{C}=\mathrm{O}$ of pyrone e), 3275$3360(\mathrm{NH}=\mathrm{NH}) ;{ }^{1} \mathrm{H}$ NMR $\left(\mathrm{DMSO}_{6}\right) \delta: 4.86\left(\mathrm{~s}, 2 \mathrm{H}, \mathrm{OCH}_{2}\right)$, 6.31-8.65 (m, 9H, Ar-H), 9.69 (s, 1H, NH) 10.24 (s. 1H, NH); ${ }^{13}$ C NMR (DMSO-d ${ }_{6}$ ) $\delta: 77.95,106.73,115.21,116.29,120.76$, 120.91, 126.91, 131.20, 131.72, 133.11, 133.37, 146.51, 148.21, 153.12, 161.03, 165.81, 165.93, 170.38, 187.42; LC-MS m/z 462 $(\mathrm{M}+)$ and $464(\mathrm{M}+2)$. Anal. calcd. for $\mathrm{C}_{21} \mathrm{H}_{13} \mathrm{ClF}_{2} \mathrm{~N}_{2} \mathrm{O}_{6}: \mathrm{C}$, 54.50; H, 2.83; N, 6.05, Found: C, 54.48; H, 2.81; N, 6.04\%.

4.2.6.3. [2-4(4-Chloro)benzoyl-2-chloro-6-fluorophenoxy]acetoN(pyrone-2-one)carbonyl hydrazide (10c). Yield: 67\%; Purity > 85\% HPLC; M.P. 117-119 ${ }^{\circ} \mathrm{C}$; FT-IR (KBr, $v_{\max } \mathrm{cm}^{-1}$ ): 1648 $(\mathrm{C}=\mathrm{O}), 1679\left(-\mathrm{CH}_{2}-\mathrm{C}=\mathrm{O}\right), 1728(\mathrm{C}=\mathrm{O}$ of pyrone e), 3275$3360(\mathrm{NH}-\mathrm{NH}) ;{ }^{1} \mathrm{H}$ NMR (DMSO-d $\left.{ }_{6}\right) \delta: 4.86\left(\mathrm{~s}, 2 \mathrm{H}, \mathrm{OCH}_{2}\right)$, 6.31-8.65 (m, 9H, Ar-H), 9.09 (s, 1H, NH), 10.03 (s, 1H, NH); ${ }^{13}$ C NMR (DMSO-d ${ }_{6}$ ) $\delta: 77.97,114.21,116.22,120.72,120.93$, 127.12, 128.69, 131.22, 131.50, 133.11, 135.91, 137.51, 146.72, 148.82, 153.11, 161.01, 164.07, 170.32, 187.38; LC-MS m/z 478 
$(\mathrm{M}+)$ and $450(\mathrm{M}+2)$. Anal. calcd. for $\mathrm{C}_{21} \mathrm{H}_{13} \mathrm{Cl}_{2} \mathrm{FN}_{2} \mathrm{O}_{6}: \mathrm{C}$, 52.63; H, 2.73; N, 5.85, Found: C, 52.62; H, 2.71; N, 5.83\%.

4.2.6.4. [2-4(4-Methyl)benzoyl-2-chloro-6-fluorophenoxy]acetoN(pyrone-2-one)carbonyl hydrazide (10d). Yield: 88\%; Purity > 78\% HPLC; M.P. $118-120{ }^{\circ} \mathrm{C}$; FT-IR (KBr, $\left.v_{\max } \mathrm{cm}^{-1}\right): 1650$ $(\mathrm{C}=\mathrm{O}), 1678\left(-\mathrm{CH}_{2}-\mathrm{C}=\mathrm{O}\right), 1728(\mathrm{C}=\mathrm{O}$ of pyrone e), 3275$3360(\mathrm{NH}-\mathrm{NH}) ;{ }^{1} \mathrm{H}$ NMR (DMSO-d 6 ) $\delta: 2.40\left(\mathrm{~s}, 3 \mathrm{H}, \mathrm{CH}_{3}\right), 4.86$ $\left(\mathrm{s}, 2 \mathrm{H}, \mathrm{OCH}_{2}\right), 6.31-8.65(\mathrm{~m}, 9 \mathrm{H}, \mathrm{Ar}-\mathrm{H}), 9.23(\mathrm{~s}, 1 \mathrm{H}, \mathrm{NH})$, 10.23 (s, $1 \mathrm{H}, \mathrm{NH}) ;{ }^{13} \mathrm{C}$ NMR $\left(\mathrm{DMSO}_{6} \mathrm{~d}_{6}\right) \delta: 21.32,77.92$, 109.21, 117.22, 122.71, 126.92, 129.12, 130.69, 131.24, 131.80, 134.11, 135.81, 138.51, 146.73, 149.83, 153.18, 161.04, 164.06, 171.32, 187.58; LC-MS $m / z 458(\mathrm{M}+)$ and $460(\mathrm{M}+2)$. Anal. calcd. for $\mathrm{C}_{22} \mathrm{H}_{16} \mathrm{ClFN}_{2} \mathrm{O}_{6}: \mathrm{C}, 57.59 ; \mathrm{H}, 3.51 ; \mathrm{N}, 6.11$, Found: C, 57.56; H, 3.50; N, 6.10\%.

\subsection{Biological studies}

4.3.1. Cell culture and in vitro treatment. All the experimental manipulations were carried out strictly under aseptic conditions in a class II biosafety cabinet (Thermo Scientific, USA). The floor of the biosafety cabinet was thoroughly sprayed and swabbed with $70 \%$ ethanol. The surface of all the vessels and other instruments used for the study were also cleaned with ethanol. The chamber was then sterilized by inbuilt UV irradiation continuously for $1 \mathrm{~h}$ before inoculation. Hands and arms inside the inoculation chamber were swabbed with ethanol before inoculation. For the present investigation, Dulbecco modified Eagle medium (DMEM) supplemented with $10 \%$ heat inactivated fetal bovine serum (FBS), penicillin-streptomycin and $0.37 \%$ sodium bicarbonate was used. The powdered DMEM was prepared with sterilized double distilled water as per the manufacturer's recommendation. The prepared media were then subjected to filtersterilization using $0.2 \mu$ Whatman filter paper. ${ }^{13}$ Further, for the present study, three different cell lines of varying origin were selected. A549, HeLa and MCF-7 cells were used for determining the $\mathrm{IC}_{50}$ values for the newly synthesized series 9a-d and 10a-d by MTT, trypan blue, LDH leakage and clonogenic assays. Cells were treated using increasing concentrations of compounds $9 \mathrm{a}-\mathbf{d}$ and 10a-d $(0,5,10,25,50$ and $100 \mu \mathrm{M}$ in DMSO) at various time intervals (0-48 h) and were then used for experiments. An appropriate vehicle control and cisplatin as a positive control were used and each experiment was repeated a minimum of three times independently.

4.3.2. MTT assay. For the evaluation of the effect of compounds 9a-d and 10a-d on cell proliferation of A549, HeLa and MCF-7 cells, an MTT assay was performed, as described earlier. ${ }^{13}$ Cells growing in exponential phase were seeded into 96-well plates in triplicate at an initial density of $3 \times 10^{4}$ cells per well in $100 \mu \mathrm{l}$ of complete medium. Following $16 \mathrm{~h}$ of incubation, compounds $\mathbf{9 a - d}$ and $\mathbf{1 0 a - d}$ were added to the culture medium at $0,5,10,25,50$ and $100 \mu \mathrm{M}$ concentrations with appropriate controls and blanks. Cells were incubated for $48 \mathrm{~h}$. Later, $10 \mu \mathrm{l} \mathrm{MTT}\left(5 \mathrm{mg} \mathrm{ml}^{-1}\right)$ reagent was added and incubated for $4 \mathrm{~h}$ at $37^{\circ} \mathrm{C}$. For solubilization of the resultant 5-(4,5-dimethyl thiazol-2-yl)-1,3-diphenyl blue (formazan) product which was obtained by reduction of MTT after the incubation period, $100 \mu \mathrm{l}$ of DMSO was added. The absorbance was measured using a multimode reader at a test wavelength of $570 \mathrm{~nm}$ and a reference wavelength of $630 \mathrm{~nm}$. Data obtained are expressed as the percentage of control mean \pm standard error of the mean (SEM) of triplicate values.

4.3.3. Trypan blue dye exclusion assay. The effects of the compounds 9a-d and 10a-d on A549, HeLa and MCF-7cells were determined by a trypan blue dye exclusion assay. ${ }^{13,14}$ A549, HeLa and MCF-7 cells were cultured and treated with or without compounds and then collected after $48 \mathrm{~h}$. The viable cells were counted by resuspending the cells in $0.4 \%$ trypan blue and the $\mathrm{IC}_{50}$ values were estimated.

4.3.4. $\mathrm{LDH}$ release assay. An $\mathrm{LDH}$ assay was performed to assess LDH release by treating A549, HeLa and MCF-7 cells with compounds 9a-d and 10a-d (0, 5, 10, 25, 50 and $100 \mu \mathrm{M}$ in DMSO) after $48 \mathrm{~h}$ of incubation, as described earlier. ${ }^{14}$ The cells were lysed using $0.1 \%$ "Triton-X100" in PBS. The amount of $\mathrm{LDH}$ released in both culture medium and cell lysate was measured at $490 \mathrm{~nm}$ using an ELISA reader. The percentage of $\mathrm{LDH}$ release was calculated as $\mathrm{LDH}$ release in the medium $(\mathrm{LDH}$ release in medium + intracellular $\mathrm{LDH}$ release) $\times 100$.

4.3.5. Colony formation assay. The colony formation assay has been the gold standard for determining the antineoplastic effects of cytotoxic compounds on cancer cell proliferation in vitro and it was performed as described earlier to determine the effect of the potent compound 9d against A549 cells. $^{22-24}$ In brief, cells were cultured in T-25 tissue culture flasks for $24 \mathrm{~h}$ and exposed to test compound 9d at $10 \mu \mathrm{M}$ and $20 \mu \mathrm{M}$ concentrations. The cells were then trypsinized, counted and seeded into a six-well plate at appropriate densities and cultured for 8 days. Colonies were fixed with methanol, stained with crystal violet $\left(0.4 \mathrm{~g} \mathrm{l}^{-1}\right)$, photographed, analyzed and counted using ImageJ (v1.48) software.

4.3.6. Migration assay. A549 cells were cultured in a sixwell plate a until they reached a confluence of $60-70 \%$. A scratch was made to form a wound using a micropipette and the monolayer was washed with growth medium. Then $2 \mathrm{ml}$ of medium containing different concentrations of test drugs was added to the respective wells, which were then incubated for $48 \mathrm{~h}$, fixed with chilled $70 \%$ ethanol and stained with crystal violet $\left(0.4 \mathrm{~g} \mathrm{l}^{-1}\right)$. Images were taken from random fields at regular time intervals using an inverted microscope (Bresser, Biolux). Finally, the percentage cell migration was calculated by comparing the final gap width to the initial gap width. ${ }^{13,25,26}$

4.3.7. In vivo rVEGF $_{165}$-induced chorioallantoic membrane (CAM) assay. An in vivo CAM model was performed to evaluate anti-angiogenesis activity, with slight modifications, as described previously. In brief, fertilized eggs were incubated, windows were made on the 3rd day, and filter paper discs loaded with test compound $9 \mathrm{~d}(10 \mu \mathrm{M})$ were placed on the CAMs. Then, after proper sealing, the eggs were reincubated for 3-4 days. Finally, the eggs were opened and changes in 
the MVD were photographed using a Sony Steady Shot DSCW610 camera. Based on the changes in the MVD, the inhibition in angiogenesis was evaluated. ${ }^{19,21,27,28}$

4.3.8. In vivo/ex vivo rVEGF $_{165}$ induced CAM assay. To confirm the angioprevention effect of compound 9d, an in vitro/ ex vivo shell-less CAM assay was performed. In brief, 2-dayold fertilized incubated eggs were cracked open and the contents were poured onto a sterilized condiment cup covered with Saran wrap. The egg preparations were covered with a sterilized petri dish and re-incubated under humidified conditions at $37^{\circ} \mathrm{C}$. On the 4 th day the egg preparations were impregnated with sterile filter discs containing rVEGF $_{165}$ followed by treatment with the compound. After $72 \mathrm{~h}$ of incubation, the change in the vascularization in both treated and untreated egg preparations was photographed using a Sony steady shot DSC-W610 camera and the blood vessels were quantified. ${ }^{20}$

4.3.9. In vivo CAM xenograft assay. An in vivo CAM xenograft model to assess angiogenesis was developed, with slight modification, as described previously. ${ }^{21,29}$ In brief, the cell line used for the present assay is human lung adenocarcinoma (A549), which was cultured as described previously. The fertilized Giriraja breed hen's eggs were procured from a local market. The eggs were thoroughly wiped with $70 \%$ alcohol and maintained at $37{ }^{\circ} \mathrm{C}$ under humidified conditions for the development of the embryo. Under aseptic conditions, 50 $\mu \mathrm{l}$ of extracellular matrix (ECM) gel was coated on the bottom of a plastic ring of dimensions $4 \mathrm{~mm} \times 4 \mathrm{~mm}$ (height $\times$ diameter). A small window was made in the fertilized eggs on the 6th day after fertilization and about $1 \mathrm{ml}$ of albumin was drawn carefully without damaging the CAM, using a sterilized syringe. The plastic rings with ECM gel were placed on the growing CAM under sterilized conditions. The rings were then adsorbed with $5 \times 10^{6}$ A549 cell suspension along with rVEGF $_{165}\left(10 \mathrm{ng} \mathrm{ml}^{-1}\right)$. The window was sealed using sterile Saran wrap and again retained for incubation. The eggs were opened on the 12th day and the tumor was separated from the CAM and photographed, and histological sections were processed for an MVD count.

4.3.10. Changes in the morphology of cell line by Giemsa staining. The untreated and treated cells with the compound 9d were trypsinized and stained with $20 \times$ Giemsa stock solution at a stain-to-cell suspension ratio of $1: 10$. Morphology and apoptotic body formations were evaluated by control versus compound 9d-treated cells. Then the cells were viewed under the 40× objective of a microscope (Biolux, Bresser Germany) and mounted with MagCam (Magnus Analytics); finally, the images were analyzed with ImageJ software. ${ }^{14,19,30}$

4.3.11. Endonuclease assay. An endonuclease assay was performed to assess compound-induced DNase activation by the methods described earlier. ${ }^{20}$ Briefly, one portion of cytosolic extracts of A549 cells prepared in lysis buffer $(10 \mathrm{mM}$ Tris-hydrochloric acid, pH 8.0, $0.1 \mathrm{mM}$ EGTA and $0.1 \%$ $\beta$-mercaptoethanol and protease inhibitors) was treated with camptothecin, a second portion was treated with compound 9d and the third portion was left untreated. Then 1\% agarose which contained $10 \mu \mathrm{g} \mathrm{ml} \mathrm{m}^{-1}$ ethidium bromide and $50 \mu \mathrm{g}$ $\mathrm{ml}^{-1}$ of hot denatured salmon-sperm DNA was plated on glass Petri dishes and allowed to solidify at room temperature. Wells were prepared in Petri dishes by suction pressure, and equal amounts of protein $(500 \mu \mathrm{g})$ from camptothecintreated, compound 9d-treated and control cells were added. The above cytosolic extracts were added to the wells and incubated for $12-18 \mathrm{~h}$ at $37{ }^{\circ} \mathrm{C}$ in a humidified chamber. An endonuclease assay was performed and the DNA cleavage zone was assessed. ${ }^{20}$ The DNA cleavage zone was then visualized under the SYBR green view of a Bio-Rad Gel documentation $^{\mathrm{TM}} \mathrm{XR}+$ Imaging system and photographed.

4.3.12. DNA fragmentation assay. Lambda phage DNA was treated with different concentrations of compound 9d. Then the DNA was resolved in $\mathbf{0 . 8 \%}$ agarose gel and fragmentation of the treated DNA was observed and documented under a Syngene Ingenius Gel documentation and imaging system. ${ }^{13,31}$

4.3.13. Immunoblots. Whole cell lysates were prepared from compound 9d-treated and untreated A549 cells using RIPA buffer (100 mM Tris, pH 7.5, $140 \mathrm{mM}$ sodium chloride, $0.1 \%$ SDS, 5 mM EDTA, 1\% "Triton-X100", 0.5\% sodium deoxycholate, and $0.5 \mathrm{mM}$ PMSF protease inhibitor cocktail). Cell lysate concentration was determined by using a biospectrophotometer and $30 \mu \mathrm{g}$ samples of lysates were resolved with $12 \%$ sodium dodecyl sulfate polyacrylamide gel electrophoresis and transferred to polyvinylidene difluoride. Immunoblot analysis was carried out for VEGF-A, caspase-3 (Santacruz Biotechnology, USA) and $\beta$-actin (BD Bioscience, USA). ${ }^{13}$

4.3.14. Annexin v apoptosis by flow cytometry. The A549 cells were seeded into a six-well plate and incubated at $37^{\circ} \mathrm{C}$ for $24 \mathrm{~h}$. The cells were treated with an $\mathrm{IC}_{50}$ concentration of compound 9d for12-15 h, trypsinized and placed into $15 \mathrm{ml}$ tubes. Then the cells were washed with $1 \times$ DPBS and resuspended in $1 \times$ binding buffer solution at a concentration of $1 \times 10^{6}$ cells per ml. Next, $100 \mu \mathrm{l}$ of the cell suspension was placed in a $1.5 \mathrm{ml}$ tube, $5 \mu \mathrm{l}$ of FITC-Annexin $\mathrm{V}$ was added and the mixture was incubated for 15 minutes at room temperature $\left(25^{\circ} \mathrm{C}\right)$ in the dark. Then $5 \mu \mathrm{l}$ of PI and $400 \mu \mathrm{l}$ of the $1 \times$ binding buffer were added to each tube and vortexed gently. Finally, the samples were analyzed using a BD Accuri C6 Flow Cytometer, BD Biosciences. ${ }^{22,32-36}$

4.3.15. Regulation of cell cycle arrest. For the cell cycle analysis, cells were seeded into a six-well plate and incubated at $37{ }^{\circ} \mathrm{C}$ for $24 \mathrm{~h}$. Then the cells were treated with an $\mathrm{IC}_{50}$ concentration of compound $9 \mathrm{~d}$ for $16 \mathrm{~h}$, trypsinized and placed into $15 \mathrm{ml}$ tubes. Further, the cells were washed with $1 \times$ DPBS, fixed in chilled $70 \%$ ethanol $\left(-20^{\circ} \mathrm{C}\right)$, then twice with $1 \times$ DPBS, resuspended in PI-RNase $(400 \mu \mathrm{l}$ of solution per million cells) and placed into $1.5 \mathrm{ml}$ tubes. Finally, the samples were mixed well and analyzed using a BD Accuri C6 Flow Cytometer, BD Biosciences. ${ }^{22,37,38}$

\section{In silico study}

Chembiodraw Ultra 14.0 software was used for building the ligands, including all hydrogen atoms. The compounds used 
for docking were converted into 3D with ChemBio3D Ultra 14.0. For the purpose of the in silico study, the AutoDock tools program was used. A conformational search of the ligand, which is considered in one of the applications of multi-conformer docking, was first approved, and all related low-energy conformations were then inflexibly located in the binding site. In order to consider the rigid conformer, rotational and translational degrees of freedom were allowed. A series of shape-based filters are used by the AutoDock process, and Gaussian shape fitting is the building block, in which scoring conformation depends on binding energies. By using AutoDock tools-1.5.6 an in silico study of the inhibitors with the VEGFR kinase domain from VEGF (PDB-2xir: A) was performed. The proteins and ligands were downloaded in three-dimensional atomic coordinates and prepared for molecular docking. A Lamarckian genetic algorithm (LGA) was applied in the program to identify appropriate binding modes and the conformation of the ligand molecules. One of the major processes of the in silico study is the addition of polar hydrogen atoms and the assignment of Kollman charges to the protein using AutoDock tools. Type grid maps have been assigned to every single atom in the protein and the ligands. Through this study a calculation has been done for the desolation maps and additional electrostatic. Using LGA, molecular docking simulations were performed as the search algorithm. With the help of the PyMol program, all molecular modeling experiments were carried out with carton and ribbon models, as shown in Fig. $12 .^{39-41}$

\section{Statistical analysis}

Statistical analysis data are shown as mean \pm SEM, and the analysis involved use of SPSS 17.0 by one-way ANOVA followed by a Student's $t$-test. Statistically significant values were represented as $* p<0.05$ and $* * p<0.01$.

\section{Conflicts of interest}

The authors declare that there are no conflicts of interest.

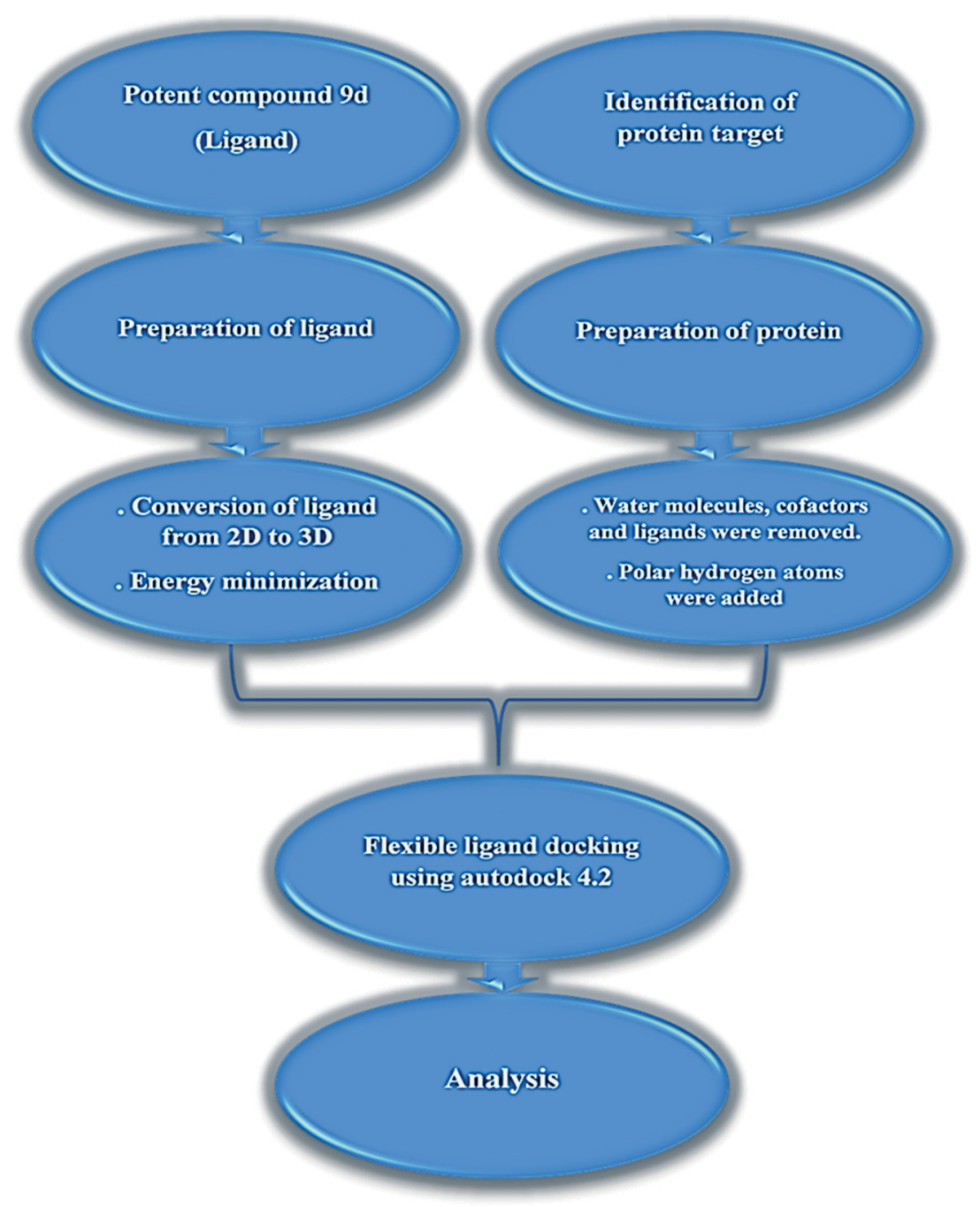

Fig. 12 Schematic representation of the docking process. 


\section{Acknowledgements}

Yasser Hussein Eissa Mohammed is thankful to the University of Hajja, Yemen, for providing financial assistance under the teacher's fellowship. Special thanks are due to Cytxon Biosolutions pvt. Ltd, Hubballi, India for cell culture assistance for the work. Also, the author expresses his thanks to Scintilla BIO-MARC pvt. Ltd, Bangalore, India for cell culture assistance. Shaukath Ara Khanum expresses sincere gratitude to the Government of Karnataka, Vision Group on Science and Technology, Bangalore for financial assistance and support [VGST/CISEE/ 2012-13/282 dated 16th March 2013] and UGC, New Delhi under the Major Research Project Scheme [F.39/ 737/2010 (SR)].

\section{References}

1 V. Vigneshwaran, P. Thirusangu, S. Madhusudana, V. Krishna, S. N. Pramod and B. T. Prabhakar, The latex sap of the 'Old World Plant'Lagenariasiceraria with potent lectin activity mitigates neoplastic malignancy targeting neovasculature and cell death, Int. Immunopharmacol., 2016, 39, 158-171.

2 B. V. Avin, T. Prabhu, C. K. Ramesh, V. Vigneshwaran, M. Riaz, K. Jayashree and B. T. Prabhakar, New role of lupeol in reticence of angiogenesis, the cellular parameter of neoplastic progression in tumorigenesis models through altered gene expression, Biochem. Biophys. Res. Commun., 2014, 448, 139-144.

3 P. Thirusangu, V. Vigneshwaran, B. V. Avin, H. Rakesh, H. M. Vikas and B. T. Prabhakar, Scutellarein antagonizes the tumorigenesis by modulating cytokine VEGF mediated neoangiogenesis and DFF-40 actuated nucleosomal degradation, Biochem. Biophys. Res. Commun., 2017, 484, 85-92.

4 B. Stoelcker, B. Ruhland, T. Hehlgans, H. Bluethmann, T. Luther and D. N. Männel, Tumor necrosis factor induces tumor necrosis via tumor necrosis factor receptor type 1-expressing endothelial cells of the tumor vasculature, Am. J. Pathol., 2000, 4, 1171-1176.

5 D. R. Senger, C. A. Perruzzi, J. Feder and H. F. Dvorak, A highly conserved vascular permeability factor secreted by a variety of human and rodent tumor cell lines, Cancer Res., 1986, 11, 5629-5632.

6 H. P. Gerber, T. H. Vu, A. M. Ryan, J. Kowalski, Z. Werb and N. Ferrara, VEGF couples hypertrophic cartilage remodeling, ossification and angiogenesis during endochondral bone formation, Nat. Med., 1999, 6, 623-628.

7 P. B. Vermeulen, G. Gasparini, S. B. Fox, M. Toi, L. Martin, P. McCulloch, F. Pezzella, G. Viale, N. Weidner, A. L. Harris and L. Y. Dirix, Quantification of angiogenesis in solid human tumours: an international consensus on the methodology and criteria of evaluation, Eur. J. Cancer, 1996, 14, 2474-2484.

8 G. Bergers, D. Hanahan and L. M. Coussens, Angiogenesis and apoptosis are cellular parameters of neoplastic progression in transgenic mouse models of tumorigenesis,
Int. J. Dev. Biol., 1998, 42, 995-1002.

9 D. Sloane, Cancer epidemiology in the United States: racial, social, and economic factors, Cancer Epidemiol., 2009, 471, 65-83.

10 K. Hotta and H. Ueoka, New cytotoxic agents: a review of the literature, Crit. Rev. Oncol. Hematol., 2005, 55, 45-65.

11 T. Prashanth, P. Thirusangu, B. V. Avin, V. L. Ranganatha, B. T. Prabhakar and S. A. Khanum, Synthesis and evaluation of novel benzophenone-thiazole derivatives as potent VEGFA inhibitors, Eur. J. Med. Chem., 2014, 87, 274-283.

12 M. Al-Ghorbani, P. Thirusangu, H. D. Gurupadaswamy, V. Girish, H. S. Neralagundi, B. T. Prabhakar and S. A. Khanum, Synthesis and antiproliferative activity of benzophenone tagged pyridine analogues towards activation of caspase activated DNase mediated nuclear fragmentation in Dalton's lymphoma, Bioorg. Chem., 2016, 65, 73-81.

13 Y. H. Eissa Mohammed, P. Thirusangu and S. A. Khanum, The anti-invasive role of novel synthesized pyridazine hydrazide appended phenoxy acetic acid against neoplastic development targeting matrix metallo proteases, Biomed. Pharmacother., 2017, 95, 375.

14 B. R. Vijay Avin, P. Thirusangu, V. L. Ranganatha, A. Firdouse, B. T. Prabhakar and S. A. Khanum, Synthesis and tumor inhibitory activity of novel coumarin analogs targeting angiogenesis and apoptosis, Eur. J. Med. Chem., 2014, 75, 211-221.

15 V. L. Ranganath, B. R. V. Avin, P. Thirusangu, T. Prashanth, B. T. Prabhakar and S. A. Khanum, Synthesis, angiopreventive activity, and in vivo tumor inhibition of novel benzophenoneebenzimidazole analogs, Life Sci., 2013, 93, 904-911.

16 E. Kumazawa, K. Hirotani, S. Clifford Burford, K. Kawaagoe, T. Miwa, I. Mitsui and A. Ejima, Synthesis and antitumor activity of novel benzophenone derivatives, Chem. Pharm. Bull., 1997, 45, 1470-1474.

17 H. D. Gurupadaswamy, V. Girish, C. V. Kavitha, S. C. Raghavan and S. A. Khanum, Synthesis and evaluation of 2,5-di(4-aryloylaryloxymethyl)- 1,3,4-oxadiazoles as anti-cancer agents, Eur. J. Med. Chem., 2013, 63, 536-543.

18 B. T. Prabhakar, S. A. Khanum, K. Jayashree, B. P. Salimath and S. Shashikanth, Antitumor and proapoptotic effect of novel synthetic benzophenone analogs in Ehrlich ascites tumor cells, Bioorg. Med. Chem. Lett., 2006, 14, 435-446.

19 Y. H. E. Mohammed, V. H. Malojirao, P. Thirusangu, M. Al-Ghorbani, B. T. Prabhakar and S. A. Khanum, The Novel 4-Phenyl-2-Phenoxyacetamide Thiazoles modulates the tumor hypoxia leading to the crackdown of neoangiogenesis and evoking the cell death, Eur. J. Med. Chem., 2018, 143, 1826-1839.

20 H. D. Gurupadaswamy, T. Prabhu, B. R. Vijay Avin, V. Vigneshwaran, M. V. Prashanth Kumar, T. S. Abhishek, V. L. Ranganatha, S. A. Khanum and B. T. Prabhakar, DAO-9 (2,5di(4-aryloylaryloxymethyl)-1,3,4-oxadiazole) exhibits p53 induced apoptogenesis through caspase-3 mediated endonuclease activity in murine carcinoma, Biomed. Pharmacother., 2014, 6, 791-797. 
21 P. Thirusangu, V. Vigneshwaran, T. Prashanth, B. V. Avin, V. H. Malojirao, H. Rakesh, S. A. Khanum, R. Mahmood and B. T. Prabhakar, BP-1T, an antiangiogenic benzophenonethiazole pharmacophore, counteracts HIF-1 signalling through p53/MDM2-mediated HIF-1 $\alpha$ proteasomal degradation, Angiogenesis, 2017, 1, 55-71.

22 M. Al-Ghorbani, P. Thirusangu, H. D. Gurupadaswamy, V. Vigneshwaran, Y. H. E. Mohammed, B. T. Prabhakar and S. A. Khanum, Synthesis of novel morpholine conjugated benzophenone analogues and evaluation of antagonistic role against neoplastic development, Bioorg. Chem., 2017, 71, 55-66.

23 N. A. Franken, H. M. Rodermond, J. Stap, J. Haveman and C. Van Bree, Clonogenic assay of cells in vitro, Nat. Protoc., 2006, 1, 2315.

24 A. Munshi, M. Hobbs and R. E. Meyn, Clonogenic cell survival assay, Chemosensitivity, 2005, 1, 21-28.

25 J. H. Chiang, J. S. Yang, C. C. Lu, M. J. Hour, S. J. Chang, T. H. Lee and J. G. Chung, Newly synthesized quinazolinone HMJ-38 suppresses angiogenetic responses and triggers human umbilical vein endothelial cell apoptosis through p53modulated Fas/death receptor signaling, Toxicol. Appl. Pharmacol., 2013, 269, 150-162.

26 M. G. Lampugnani, Cell migration into a wounded area in vitro, Adhesion Protein Protocols, 1999, pp. 177-182.

27 R. Auerbach, R. Lewis, B. Shinners, L. Kubai and N. Akhtar, Angiogenesis assays: a critical overview, Clin. Chem., 2003, 1, 32-40.

28 K. Norrby, In vivo models of angiogenesis, J. Cell. Mol. Med., 2006, 3, 588-612.

29 W. Schneiderhan, F. Diaz, M. Fundel, S. Zhou, M. Siech, C. Hasel, P. Möller, J. E. Gschwend, T. Seufferlein, T. Gress and G. Adler, Pancreatic stellate cells are an important source of MMP-2 in human pancreatic cancer and accelerate tumor progression in a murine xenograft model and CAM assay, J. Cell Sci., 2007, 3, 512-519.

30 P. Perry and S. Wolff, New Giemsa method for the differential staining of sister chromatids, Nature, 1974, 5471, 156-158.

$31 \mathrm{X}$. Liu, H. Zou, C. Slaughter and X. Wang, DFF, a heterodimeric protein that functions downstream of caspase-3 to trigger DNA fragmentation during apoptosis, Cell, 1997, 2, 175-184.
32 C. Bai, T. Chen, Y. Cui, T. Gong, X. Peng and H. M. Cui, Effect of high fluorine on the cell cycle and apoptosis of renal cells in chickens, Biol. Trace Elem. Res., 2010, 1-3, 173-180.

33 Y. Fan, J. Cheng, S. A. Vasudevan, R. H. Patel, L. Liang, X. $\mathrm{Xu}$, Y. Zhao, W. Jia, F. Lu, H. Zhang and J. G. Nuchtern, TAK1 inhibitor 5Z-7-oxozeaenol sensitizes neuroblastoma to chemotherapy, Apoptosis, 2013, 10, 1224-1234.

34 G. Koopman, C. P. Reutelingsperger, G. A. Kuijten, R. M. Keehnen, S. T. Pals and M. H. Van Oers, Annexin V for flow cytometric detection of phosphatidylserine expression on $\mathrm{B}$ cells undergoing apoptosis, Blood, 1994, 5, 1415-1420.

35 I. Vermes, C. Haanen, H. Steffens-Nakken and C. Reutellingsperger, A novel assay for apoptosis flow cytometric detection of phosphatidylserine expression on early apoptotic cells using fluorescein labelled annexin V, J. Immunol. Methods, 1995, 1, 39-51.

36 E. Chu, D. M. Koeller, J. L. Casey, J. C. Drake, B. A. Chabner, P. C. Elwood, S. Zinn and C. J. Allegra, Autoregulation of human thymidylate synthase messenger RNA translation by thymidylate synthase, Proc. Natl. Acad. Sci. U. S. A., 1991, 20, 8977-8981.

37 P. Pozarowski and Z. Darzynkiewicz, Analysis of cell cycle by flow cytometry, Methods Mol. Biol., 2004, 2, 301-311.

38 M. G. Ormerod, B. Tribukait and W. Giaretti, Consensus report of the task force on standardisation of DNA flow cytometry in clinical pathology, Anal. Cell. Pathol., 1998, 2, 103-110.

39 X. H. Liu, H. F. Liu, J. Chen, Y. Yang, B. A. Song, L. S. Bai, J. X. Liu, H. L. Zhu and X. B. Qi, Synthesis and molecular docking study of novel coumarin derivatives containing 4, 5-dihydropyrazole moiety as potential antitumor agents, Bioorg. Med. Chem. Lett., 2010, 19, 5705-5708.

40 K. M. Khan, F. Rahim, A. Wadood, N. Kosar, M. Taha, S. Lalani, A. Khan, M. I. Fakhri, M. Junaid, W. Rehman and M. Khan, Synthesis and molecular docking studies of potent $\alpha$-glucosidase inhibitors based on biscoumarin skeleton, Eur. J. Med. Chem., 2014, 81, 245-252.

41 A. S. El-Azab, M. A. Al-Omar, A. M. Alaa, N. I. Abdel-Aziz, A. A. Magda, A. M. Aleisa, M. M. Sayed-Ahmed and S. G. Abdel-Hamide, Design, synthesis and biological evaluation of novel quinazoline derivatives as potential antitumor agents: molecular docking study, Eur. J. Med. Chem., 2010, 9, 4188-4198. 